\title{
Odjeci hrvatskoga proljeća u Osijeku
}

\author{
Domagoj TOMAS* - MARIJANA BOŠNJAK** \\ • https://doi.org/10.31823/d.28.4.4 • \\ UDK: $323.1^{*} 94(497.5$ Osijek)“1971“ • Izvorni znanstveni rad \\ Primljeno: 23. studenoga 2019. • Prihvaćeno: 2. prosinca 2020.
}

${ }^{*}$ Doc. dr. sc. Domagoj Tomas, Filozofski fakultet u Osijeku Sveučilišta J. J. Strossmayera u Osijeku, L. Jägera 9, 31000 Osijek, Hrvatska, domagoj. tomas@gmail.com

** Marijana Bošnjak, mag. educ. hist. et mag. educ. philol. croat., Matije Gupca 122, 32271

Andrijaševci, Hrvatska, marijanabosnjak5@ gmail.com

Sažetak: U članku se raščlanjuju zbivanja koja se mogu podvesti pod zajednički nazivnik hrvatskoga proljeća na lokalnom osječkom području. Pritom se u uvodnom dijelu polazi od terminološkoga i sadržajnoga određenja općega fenomena hrvatskoga proljeća, uz prepoznavanje nekolicine dogadaja koji su mu prethodili te omogućili razvoj. Zatim slijedi prijedlog periodizacije hrvatskoga proljeća s trima fazama te predstavljanje njegovih triju žarišta, slokalnim osjeckkim ekvivalentima (>reformno « krilo OK-a SKH-a Osijek, OMH Osijek i SSO). U nastavku članka u pojedinačnim se poglavljima analiziraju zbivanja u okviru osječkih društveno-političkih organizacija, OMH-a Osijek i osječkoga studentskoga pokreta, koja se mogu staviti u kontekst hrvatskoga proljeća. Utvrđena je izravna povezanost proljećarskih gibanja u Zagrebu sonima koja će uslijediti u Osijeku, pomoću raznih uobičajenih komunikacijskih kanala, poput sudjelovanja članova CK-a SKH-a na sjednicama lokalnih društveno-političkih organizacija ili pak javnih predavanja istaknutih članova $\mathrm{MH}$-a iz Zagreba u organizaciji OMH-a Osijek. Također, u konačnici se pokazalo da je stanje u Zagrebu dobrim dijelom bilo preslikano i na osječko područje u vrijeme kulminacije hrvatskoga proljeća, uzimajući u obzir društveno-političke organizacije, $M H$ i studente, $s$ jedinim izuzetkom nešto kasnije pojave proljećarskih ideja u Osijeku u odnosu na Zagreb.

Ključne riječi: hrvatsko proljeće, Osijek, društveno-političke organizacije, Matica hrvatska, studenti, socijalistička Jugoslavija.

\section{Uvod}

Hrvatska historiografija u posljednjih se 15-ak godina ozbiljnije posvetila istraživanju fenomena hrvatskoga proljeća, što 
je rezultiralo nastankom monografija ${ }^{1}$ i zbornika radova ${ }^{2}$ posvećenih tom fenomenu. Tu je i čitav niz sinteza moderne i suvremene hrvatske povijesti, a među njima svojom iscrpnošću i kvalitetom $u$ analizi razdoblja hrvatskoga proljeća prednjače one Dušana Bilandžića ${ }^{3}$ i Zdenka Radelića ${ }^{4}$. Historiografskim studijama prethodila je objava dijela izvornoga arhivskoga gradiva ${ }^{5}$ vezanoga uz hrvatsko proljeće, kao i čitavoga niza djela ideološki heterogenih autora s područja memoarske publicistike, ${ }^{6}$ što se nastavilo u kontinuitetu sve do danas, a vjerujemo da se i u budućnosti možemo nadati sličnim publikacijama. Uglavnom, do toga je trenda došlo stvaranjem društveno-političkih preduvjeta, odnosno demokratizacijom početkom 90 -ih godina prošloga stoljeća, nakon gotovo dvaju deseteljeća koja su najčešće označavana terminom »hrvatske šutnje «. Ipak, s obzirom na prostor koji hrvatsko proljeće zauzima u kulturi sjećanja, odnosno kolektivnoj memoriji, središnjem narativu nacionalne povijesti, obrazovnom sustavu i političkom diskursu hrvatskoga društva, vrlo je malo objavljenoga arhivskoga gradiva vezanoga uz taj fenomen.

Autorima je temeljna motivacija za početak istraživanja koje je rezultiralo nastankom ovoga članka bio uočeni opći deficit literature o hrvatskom proljeću na po-

${ }^{1}$ H. KLASIĆ, Hrvatsko proljeće u Sisku, Zagreb, 2006.; D. DUKOVSKI, Istra i Rijeka u Hrvatskome proljeću, Zagreb - Pula, 2007.; T. PONOŠ, Na rubu revolucije - studenti '71., Zagreb, 2007.; N. ZELIĆ, Hrvatsko proljeće i bački Hrvati, Subotica, 2009.; W. KRAŠIĆ, Hrvatsko proljeće i hrvatska politička emigracija, Zagreb, 2018.; A. BATOVIĆ, Hrvatsko proljeće i svijet: Hrvatska u vrtlogu svjetskih zbivanja 1966. - 1972., Zadar, 2019.

${ }^{2}$ T. JAKOVINA (ur.), Hrvatsko proljeće 40 godina poslije, Zagreb, 2012.; I. ZIDIĆ (ur.), Hrvatska i Hrvatsko proljeće 1971., Zagreb, 2017.

${ }^{3}$ Dušan Bilandžić u svojoj je studiji razdoblju hrvatskoga proljeća posvetio stotinjak stranica, nudeći prilično uravnoteženu raščlambu složenih procesa koji su se odvijali u tom razdoblju. Više: D. BILANDŽIĆ, Hrvatska moderna povijest, Zagreb, 1999., 513-518.; 553-628.; 644-656.

${ }^{4}$ Zdenko Radelić u svojoj je studiji razdoblju hrvatskoga proljeća posvetio pedesetak stranica, također nudeći prilično uravnoteženu raščlambu složenih procesa koji su se odvijali u tom razdoblju. Više: Z. RADELIĆ, Hrvatska u Jugoslaviji 1945. - 1991., Zagreb, 2006., 379-433.

${ }^{5}$ M. PIŠKOVIĆ (ur.), Sječa Hrvatske u Karađorđevu 1971., Zagreb, 1994.; J. BRATULIĆ (ur.), Izvještaj o kontroli zakonitosti rada Matice hrvatske, Zagreb, 2002.; M. MAĐOR (ur.), Hrvatsko proljeće: presuda partije, Zagreb, 2003.; I. ZIDIĆ, Slučaj Alilović, Zagreb - Grude, 2011.

${ }^{6}$ M. TRIPALO, Hrvatsko proljeće, Zagreb, 1990.; J. BILIĆ, '71, koja je to godina?, Zagreb, 1990.; S. DABČEVIĆ-KUČAR, 71: hrvatski snovi i stvarnost, Zagreb, 1997.; H. ŠOŠIĆ, Slom hrvatskog komunističkog proljeća 1971., Zagreb, 1997.; D. KASTRATOVIĆ, Proljeće moderne Hrvatske, Zagreb, 2002.; Z. BARTOVČAK, Svjedočenje jednog sudionika u povijesnim zbivanjima 1971. godine, Karlovac, 2002.; M. BALETIĆ, Hrvatska simultanka, Zagreb, 2003.; V. VUKOV, Tvoja zemlja, Zagreb, 2003.; T. ĐURIĆ, Zašto su šutjela lepoglavska zvona: Hrvatsko proljeće u Varaždinu i Čakovcu 1971., Samobor, 2004.; J. ŠENTIJA, Razgovori s Mikom Tripalom o Hrvatskom proljeću, Zagreb, 2005.; J. IVIČEVIĆ, Iz novije hrvatske povijesti, Zagreb, 2008.; M. PLANINC, Čisti računi Željezne lady: sjećanja, Zagreb, 2011.; S. LAJNERT, Hrvatsko proljeće na željeznici, Zagreb, 2013.; T. MIČIĆ, U potrazi za Hrvatskom, Zagreb, 2019. itd. 
dručju Slavonije, Srijema i Baranje, a posebice izostanak sustavne historiografske obrade toga fenomena na području grada Osijeka. Istina, o hrvatskom proljeću u Slavoniji i Baranji objavljen je jedan kraći članak ${ }^{7}$ Ivice Vrkića, no riječ je u prvom redu o tekstu memoarsko-publicističke, a ne historiografske naravi.

Ciljevi članka jesu prikaz i analiza zbivanja na lokalnoj osječkoj razini koja se mogu podvesti pod zajednički nazivnik hrvatskoga proljeća te njihovih korelacija s ostalim srodnim gibanjima u Socijalističkoj Federativnoj Republici Jugoslaviji (dalje: SFRJ), i onima unutar Socijalističke Republike Hrvatske (dalje: SR Hrvatske) i onima izvan nje, uzimajući u obzir Socijalističku Republiku Bosnu i Hercegovinu (dalje: SR BiH) (Mostar i Sarajevo) te Socijalističku Autonomnu Pokrajinu Vojvodinu (dalje: SAP Vojvodina) (Subotica). Pritom će se pokušati dokazati osnovna hipoteza o izravnom utjecaju zagrebačke jezgre hrvatskoga proljeća na razvoj zbivanja na lokalnoj razini u Osijeku u istom razdoblju, dok će kao nadgradnja poslužiti hipoteza o prisutnosti lokalnih žarišta hrvatskoga proljeća u Osijeku koja su ekvivalentna središnjim žarištima u Zagrebu te podrazumijevaju »reformno « krilo Općinskoga komiteta Saveza komunista Hrvatske Osijek (dalje: OK SKH Osijek), Ogranak Matice hrvatske u Osijeku (dalje: OMH Osijek) i osječku studentsku organizaciju.

Za prikaz i analizu zbivanja uglavnom je korišteno neobjavljeno izvorno arhivsko gradivo iz Državnoga arhiva u Osijeku (dalje: DAOS-a), ${ }^{8}$ zatim relevantni objavljeni izvori te na koncu periodičke publikacije, historiografska literatura i memoarska publicistika.

Članak je strukturiran na način da pojedina poglavlja tematski pokrivaju aktivnosti relevantnih društveno-političkih subjekata, odnosno žarišta hrvatskoga proljeća na lokalnoj osječkoj razini, uz kraće uvodno poglavlje kojim se ta zbivanja dodatno šire kontekstualiziraju.

\section{Hrvatsko proljeće kao povijesni fenomen}

Hrvatskim proljećem ${ }^{9} \mathrm{u}$ historiografiji se uvriježeno koristi kao zajedničkim nazivnikom kojim se objašnjava niz političkih, društvenih i kulturnih gibanja koja su kulminaciju doživjela tijekom 1970./1971., a svoje su ishodište imala u rani-

\footnotetext{
${ }^{7}$ I. VRKIĆ, Hrvatsko proljeće u Slavoniji i Baranji, u: I. ZIDIĆ (ur.), Hrvatska i Hrvatsko proljeće 1971., 359-367.

${ }^{8}$ Riječ je o sljedećim arhivskim fondovima: Općinski komitet SKH Osijek (HR-DAOS-324), Međuopćinska konferencija SKH Osijek (HR-DAOS-963), Općinski odbor SSRN Hrvatske Osijek (HR-DAOS-1113), Pododbor Matice hrvatske u Osijeku (HR-DAOS-939).

${ }^{9}$ Negdje u izvorima i literaturi moguće je pronaći i naziv »masovni pokret« (MASPOK), posebice kod političkih protivnika hrvatskoga proljeća.
} 
jim zbivanjima koja su dovela do »puzajuće « liberalizacije i demokratizacije ${ }^{10} \mathrm{u}$ SR Hrvatskoj u drugoj polovici 60 -ih godina 20 . st. Među tim zbivanjima vrijedi izdvojiti tri događaja koja će pokrenuti kasnije procese. Prvi među njima jest potpisivanje Protokola o odnosima između Svete stolice i SFRJ-a ${ }^{11} 1966$. godine, čime je postupno otopljavanje odnosa između SFRJ-a i Svete stolice, koji su bili prekinuti još od trenutka proglašenja zagrebačkoga nadbiskupa Alojzija Stepinca kardinalom 1953. godine, dobilo još jedan mali zamah. Kao drugi događaj vrijedi navesti tzv. Brijunski plenum iz 1966., odnosno četvrtu sjednicu Centralnoga komiteta Saveza komunista Jugoslavije (dalje: CK SKJ), ${ }^{12}$ na kojem je došlo do smjene Aleksandra Rankovića sa svih dužnosti, što je dovelo do postupnoga slabljenja uloge jugoslavenske civilne obavještajne službe. ${ }^{13}$ Treći događaj jest objava Deklaracije o nazivu i položaju hrvatskog književnog jezika ${ }^{14}$ (dalje: Deklaracije) 1967. godine, nakon koje dolazi do postupnoga otvaranja identitetskih pitanja, a napose hrvatskoga nacionalnoga pitanja u SFRJ-u.

Zapravo, kada se govori o trajanju hrvatskoga proljeća, može se reći da ne postoji suglasnost hrvatske historiografije o graničnim točkama toga fenomena. Igor Zidić tvrdi da je Miko Tripalo, govoreći »o desetak godina Hrvatskog proljeća «, nepravedno smještao njegov početak u 1961. godinu, čineći tako i Rankovićev SDS jed-

\footnotetext{
${ }^{10}$ Pod $\gg$ puzajućom « liberalizacijom i demokratizacijom obično se podrazumijeva niz društvenih, kulturnih i političkih procesa koji su se javili u drugoj polovici 60 -ih godina 20. st. Oni su doveli do širih javnih rasprava o temama koje su ranije bile slabije zastupljene ili su zaobilažene u javnom prostoru SR Hrvatske, poput ekonomske liberalizacije i nacionalnoidentitetskih pitanja. Isto razdoblje obilježeno je i porastom broja te naklade raznih periodičkih publikacija, među kojima i onih u izdanju Matice hrvatske, a došlo je i do zamjetnoga povećanja utjecaja zapadnjačke popularne kulture i potrošačkoga društva, što se najčešće označava procesom vesternizacije. Više o procesu vesternizacije: I. DUDA, U potrazi za blagostanjem: o povijesti dokolice i potrošačkog društva u Hrvatskoj 1950-ih i 1960-ih, Zagreb, 2005.; R. VUČETIĆ, Koka-kola socijalizam. Amerikanizacija jugoslovenske popularne kulture šezdesetih godina XX veka, Beograd, 2012.

${ }^{11}$ Protokol o odnosima između Svete stolice i SFRJ-a potpisan je 25. lipnja 1966., a potpisnik uime Svete stolice bio je msgr. Agostino Casaroli, dok je u ime SFRJ-a dokument potpisao Milutin Morača, član Saveznoga izvršnoga vijeća i predsjednik Savezne komisije za vjerska pitanja.

${ }^{12}$ Četvrti plenum CK-a SKJ-a održan je 1. srpnja 1966. na Brijunima.

${ }^{13}$ Jugoslavenska civilna obavještajna služba do 1964. nosila je naziv Uprava državne bezbjednosti (dalje: UDBA), a nakon 1964. nosi naziv Služba državne sigurnosti (dalje: SDS).

${ }^{14}$ Deklaracija o nazivu i položaju hrvatskog književnog jezika sastavljena je u Matici hrvatskoj 9. ožujka 1967., a objavljena 17. ožujka 1967. u zagrebačkom listu Telegram. Njome se tražio ravnopravan položaj hrvatskoga jezika u jugoslavenskoj federaciji, slobodno oblikovanje hrvatskoga jezika u skladu s hrvatskom jezičnom tradicijom te puna afirmacija hrvatskoga jezika u svim sferama života. Deklaraciju su osudile komunističke vlasti, a mnogi njezini potpisnici bili su sankcionirani.
} 
nim od sudionika, ${ }^{15}$ zbog čega on, kao i većina drugih povjesničara ${ }^{16}$ i sudionika hrvatskoga proljeća, ${ }^{17}$ njegov početak vezuje uz objavu Deklaracije. Takvu početnu dataciju podržavaju i Radelić i Darko Dukovski, koji se razilaze tek oko određenja završne datacijske točke. Dok Radelić završetak hrvatskoga proljeća, koje metaforički naziva i »jesen Hrvatskog proljeća «, smješta u 1971., odnosno zbivanja vezana uz pad hrvatskoga partijskoga rukovodstva i uhićenja studenata tijekom studentskoga štrajka, ${ }^{18}$ Dukovski trajanje hrvatskog proljeća produžuje do uhićenja hrvatskih intelektualaca 1972 . godine. ${ }^{19}$ Osim ustaljenoga određenja početka hrvatskoga proljeća 1967., u hrvatskoj su historiografiji prisutne druge datacije koje za početak hrvatskoga proljeća uzimaju 10. sjednicu Centralnoga komiteta Saveza komunista Hrvatske (dalje: CK SKH) iz $1970 .{ }^{20}$ te Svibanjsko savjetovanje iz 1968. ${ }^{21}$ Takvim historiografskim neusklađenostima sigurno je doprinijela činjenica da hrvatsko proljeće uokviruje povijesni kontekst liberalizacije koja je trajala tijekom šezdesetih godina, a čije trajanje također nije precizirano. Josip Mihaljević tvrdi da su procesi liberalizacije trajali od Osmoga kongresa SKJ-a, odnosno od 1964. do 1972., ${ }^{22}$ dok Ivan Rogić kao granične godine uzima 1965. i 1970., ${ }^{23}$ kao i Radelić koji početak procesa liberalizacije smješta u sredinu šezdesetih. ${ }^{24}$ Drugi autori liberalizacijske procese smještaju u čitavo desetljeće, smatrajući da su se manifestirali u više događaja: Zakonom o amnestiji kojim je od 1962. omogućena legalizacija političke emigracije kao ekonomske, ${ }^{25}$ donošenjem jugoslavenskoga Ustava 1963., kojim je, među ostalim, ozakonjena sloboda tiska i drugih medija,

${ }^{15}$ I. ZIDIĆ, Upravna tijela Matice hrvatske, odnos snaga i društvena previranja u razdoblju 1966. 1971., u: ISTI (ur.), Hrvatska i Hrvatsko proljeće 1971., 52.

${ }^{16}$ M. ZUBAK, Hrvatsko proljeće: Interpretacija komunističkog naslijeđa u postkomunističkoj Hrvatskoj, u: I. ZIDIĆ (ur.), Hrvatska i Hrvatsko proljeće 1971., 508.

${ }^{17}$ D. BUDIŠA, Hrvatska i hrvatsko proljeće u povijesnom kontekstu, u: I. ZIDIĆ (ur.), Hrvatska i Hrvatsko proljeće 1971., 21.

${ }^{18}$ Z. RADELIĆ, Hrvatska u Jugoslaviji 1945. - 1991., 279., 451.

${ }^{19}$ D. DUKOVSKI, Hrvatsko proljeće u Istri i Rijeci 1970. - 1972., u: I. GRAOVAC (ur.), Dijalog povjesničara-istoričara 10/2, Osijek, 2005., 141.

${ }^{20}$ D. BILANDŽIĆ, Moderna hrvatska povijest, 539.

${ }^{21}$ H. KLASIĆ, Svibanjsko savjetovanje 1968.: ekonomsko-politička platforma Hrvatskog proljeća, u: T. JAKOVINA (ur.), Hrvatsko proljeće 40 godina poslije, 57.

${ }^{22}$ J. MIHALJEVIĆ, Liberalizacija 1960-ih godina - podloga Hrvatskog proljeća, u: I. ZIDIĆ (ur.), Hrvatska i Hrvatsko proljeće 1971., 271-273.

${ }^{23}$ I. ROGIĆ, O sudionicima liberalizacije šezdesetih godina 20. stoljeća u Hrvatskoj, u: I. ZIDIĆ (ur.), Hrvatska i Hrvatsko proljeće 1971., 95.

${ }^{24}$ Z. RADELIĆ, Hrvatska u Jugoslaviji 1945. - 1991., 279.

${ }^{25}$ J. MIHALJEVIĆ, Liberalizacija 1960-ih godina - podloga Hrvatskog proljeća, 267. 
donošenjem zakona Savezne skupštine 1965. kojima su proklamirane gospodarske i tržišne reforme te je legaliziran privremeni rad u inozemstvu, ali ponajviše tzv. Brijunskim plenumom i potpisivanjem Protokola o odnosima između Svete stolice i SFRJ-a $1966 .{ }^{26}$ Dakle, iako su svojevrsni liberalni ustupci postojali i u prvoj polovici šezdesetih, liberalizacija zamah doživljava tek nakon Rankovićeva pada.

Prema tomu u periodizaciji možemo govoriti o trima fazama hrvatskoga proljeća. Pripremna faza uslijedila je nakon liberalizacijskoga razdoblja 60-ih, a obuhvaća razdoblje od objave Deklaracije 1967. pa do proljeća 1971., kada slijedi zrela faza u kojoj dolazi do kulminacije političkih zbivanja te očitoga raskola između reformne i konzervativne struje u CK-u SKH-a, što se završava političkim porazom reformne struje u prosincu 1971. Treća faza obuhvaća slom hrvatskoga proljeća te neposrednu postproljećarsku represiju.

Također, tri su skupine u historiografskoj literaturi prepoznate kao žarišta hrvatskoga proljeća: reformno krilo CK-a SKH-a, Matica hrvatska (dalje: MH) i studentski pokret. Reformno krilo CK-a SKH-a nastojalo je ostati u okviru službene politike, zalažući se za očuvanje postojećega sustava te se usmjeravajući u prvom redu na ekonomska pitanja. Njegovi predvodnici bili su Savka Dabčević-Kučar, Pero Pirker, Marko Koprtla, Srećko Bijelić, Ivan Šibl, Dragutin Haramija i dr., a valja im pridodati i člana Izvršnoga biroa Predsjedništva SKJ-a Miku Tripala te predsjednika Saveza socijalističke omladine Hrvatske ${ }^{27}$ (dalje: SSOH-a) Ivicu Vrkića. Njima nasuprot pozicije su zauzeli Vladimir Bakarić, Jakov Blažević, Milka Planinc, Jure Bilić, Jelica Radojčević, Ema Derossi-Bjelajac, Milutin Baltić, Dušan Dragosavac, Ante Josipović $^{28}$ i dr. MH krajem 60-ih, a posebno u jeku hrvatskoga proljeća 1970./1971. počela se pretvarati u svojevrsni supstitut organizirane političke oporbe,$^{29}$ propitujući u nekim trenutcima i sam sustav te otvarajući identitetska pitanja. U njezinu rukovodstvu isprofilirala se tada nekolicina vodećih hrvatskih intelektualaca koji su sudjelovali u hrvatskom proljeću, uključujući Vladu Gotovca, Marka Veselicu, Franju Tuđmana, Vlatka Pavletića, Jozu Ivičevića, Šimu Đodana, Hrvoja Šošića i dr. Studentski pokret kao treća struja hrvatskoga proljeća pokazao se najradikalnijim u pokušajima realizacije proljećarskih ideja, ozbiljno propitujući komunistički sustav i jugoslavenski državni okvir te stavljajući težište na identitetska pitanja, posebice ono nacionalne emancipacije hrvatskoga naroda u SFRJ. Među najvažnije

${ }^{26}$ B. NOVAK, Hrvatski politički vrh i sloboda misli i novinstva u Hrvatskom proljeću, u: I. ZIDIĆ (ur.), Hrvatska i Hrvatsko proljeće 1971., 122., 128., 130-131.

${ }^{27}$ Savez omladine Hrvatske bio je krovna društvenopolitička organizacija za indoktrinaciju mladih u SFRJ-u, ali i prostor ograničene mogućnosti samoorganiziranja mladih u takvim okolnostima.

${ }^{28}$ Antu Josipovića mnogi će svrstati među one koji su se našli negdje između dviju navedenih struja.

${ }^{29}$ Isto je posvjedočio i Vrkić u svome članku. Vidi: I. VRKIĆ, Hrvatsko proljeće u Slavoniji i Baranji, 363. 
studentske lidere koji su djelovali u idejnoj koheziji s hrvatskim proljećem vrijedi izdvojiti Dražena Budišu, Antu Paradžika, Ivana Zvonimira Čička, Gorana Dodiga i dr. Među tadašnjim studentima imali su i protivnike, a neki od istaknutijih bili su Damir Grubiša, Žarko Puhovski i dr.

Koordinacija djelovanja tih triju žarišta koja su okrupnjavala najveći dio proljećarskih skupina bila je povremena i djelomična, a uz njih vrijedi navesti i čitav niz drugih institucija koje su u svojim redovima imale istaknute proljećare, poput Društva književnika Hrvatske, Matice iseljenika Hrvatske, Instituta za historiju radničkoga pokreta Hrvatske, Zajednice samostalnih pisaca TIN i dr. Tu su i brojni časopisi, novine te druge periodičke publikacije, ${ }^{30}$ koje su često izlazile upravo kao glasila navedenih institucija. Katolička Crkva bila je poprilično politički pasivna, što se može objasniti konkretnim rezultatima vatikanske Ostpolitik ${ }^{31} \mathrm{u}$ SFRJ-u, odnosno potpisivanjem Protokola o odnosima između Svete stolice i SFRJ-a, koji je donio svojevrsno olakšavanje djelovanja Katoličkoj Crkvi, ali i Drugim vatikanskim koncilom, na kojem je Zakonom kanonskoga prava svećenstvu određeno da se suzdržava od aktivnoga sudjelovanja u političkim procesima stranačkom pripadnošću ili javnim stranačkim oprjedjeljenjem.

Treba istaknuti da u kontekstu hrvatskoga proljeća valja promatrati i neka politička, društvena i kulturna gibanja među Hrvatima izvan SR Hrvatske, u prvom redu tzv. slučaj Alilović ${ }^{32}$ u Mostaru, objavu Sarajevske deklaracije o hrvatskom jeziku $1971 .{ }^{33}$ te pojavu Subotičke Danice ${ }^{34}$ iste godine.

${ }^{30}$ Među časopisima i novinama valja izdvojiti Hrvatski tjednik, Hrvatski gospodarski glasnik, Hrvatsko sveučilište, Hrvatski književni list, Kritiku, Omladinski tjednik, Studentski list, Telegram, Vjesnik, Vjesnik $u$ srijedu, Glas koncila itd.

${ }^{31}$ Ostpolitik, vatikanska istočna politika, čiji je arhitekt Agostino Casaroli, a koja je označavala stvaranje preduvjeta za normalizaciju odnosa te mirnu koegzistenciju između Katoličke Crkve i komunističkih vlada u istočnoj Europi, obilježivši razdoblje 60-ih i 70-ih godina 20. st. Više: A. CASAROLI, Mučeništvo strpljivosti. Sveta Stolica i komunističke zemlje 1963. - 1989., Zagreb, 2001., 299-362.

${ }^{32}$ Riječ je o slučaju profesora Ivana Alilovića, koji je 1970. optužen i osuđen na zatvorsku kaznu za nacionalističko djelovanje pomoću OMH-a Mostar, koji u to vrijeme nije ni postojao u Mostaru. Više: I. ZIDIĆ, Slučaj Alilović.

${ }^{33}$ Sarajevska deklaracija o hrvatskom jeziku bila je »sestrinska « deklaracija o hrvatskom jeziku Deklaraciji o nazivu i položaju hrvatskog književnog jezika objavljenoj 1967. Objavljena je u Sarajevu 28. siječnja 1971., pod naslovom »Kada ćemo odgovoriti Grgi Gamulinu? «, a inicirao ju je književnik Mile Pešorda. Uključujući inicijatora, njezini su potpisnici bili sedmorica hrvatskih književnika iz Bosne i Hercegovine: Vitomir Lukić, Mile Pešorda, Nikola Martić, Veselko Koroman, Mirko Marjanović, Vladimir Pavlović i Stanko Bašić. U tekstu su izrazili jasno oprjedjeljenje za hrvatsku nacionalnu i kulturnu suverenost i jednakopravnost s drugim narodima u $\mathrm{BiH}$. Njezine potpisnike progonila je jugoslavenska vlast.

${ }^{34}$ Subotička Danica, najstariji crkveno-narodni kalendar Hrvata u Bačkoj. Pokrenuo ga je 1884. svećenik Pajo Kujundžić, a tijekom povijesti imao je nekoliko prekida u izlaženju i mijenjao je ime. 


\section{Društveno-političke organizacije u Osijeku u hrvatskom proljeću}

U ovom će se poglavlju na početku analizirati odnos partijskih organizacija prema Deklaraciji. Iako se godišnja konferencija 29., 33. i 41. teritorijalne organizacije ${ }^{35}$ održala 19. ožujka, dakle samo dva dana nakon objave Deklaracije, a kojoj je prisustvovao i član političkoga aktiva OK-a SKH-a Dušan Bosanac, do očitovanja o Deklaraciji tada nije došlo. ${ }^{36}$ Naime, ako se u obzir uzme činjenica da ju je Izvršni komitet CK-a SKH-a (dalje: IK CK SKH) označio neprihvatljivom četiri dana nakon objave, a Josip Broz Tito devet dana kasnije u govoru u Prištini, ${ }^{37}$ primjetno je da su organizacije u Osijeku čekale reakciju partijskoga vrha i Tita, odnosno CK-a SKH-a u odnosu prema kojem je OK SKH Osijek ${ }^{38}$ bio subordiniran is kojim je bio neposredno povezan jer je morao provoditi direktive i upute CK-a SKH-a. ${ }^{39}$ Dakle tek nakon reakcije partijskoga vrha kreću masovnije osude Deklaracije u Osijeku, koje su počele 25. ožujka 1967. sastavljanjem protestnoga pisma protiv Deklaracije na Radničkom sveučilištu Božidar Maslarić, ${ }^{40}$ a nastavljene su očitovanjem partijskih organizacija tijekom travnja, odnosno tek nakon Titova očitovanja u Prištini.

Pasivnost OK-a SKH-a Osijek zasmetala je anonimnom diskutantu koji je tijekom očitovanja 1. odjeljenja organizacije SK-a Feđe Milića o Deklaraciji prozvao čelnike OK SKH-a Osijek da bi se trebali očitovati o Deklaraciji, »kao i o pitanju discipline malo više pozabaviti «. Tih se dana Deklaracija našla na dnevnom redu i drugih partijskih organizacija poput 1., 17., 25., 26. i 27. teritorijalne organizacije, a 5. travnja 1967. na skupu 27. teritorijalne organizacije izrečena je $\gg$ oštra osuda (...) potpisnika $\ll$ Deklaracije. Osim šest teritorijalnih organizacija, o Deklaraciji se raspravljalo i u deset osječkih poduzeća kao što su Dilj, Drava trgovačko poduzeće, Kanaliza-

Kalendar je izlazio neprekidno od 1884. do 1914., a prekid je uslijedio za vrijeme Prvoga svjetskoga rata. Ponovno izlazi od 1919. do 1941., kada prestaje izlaziti zbog izbijanja Drugoga svjetskoga rata. Obnovljen je 1945., ali je nakon 1946. zabranjen. Kalendara nije bilo sve do 1971. kada je izašao samo za 1971. i 1972., nakon čega mu je ponovno zabranjeno izlaženje, sve do 1984., od kada redovito izlazi.

${ }^{35}$ Ustroj SKH-a na lokalnoj razini u analiziranom razdoblju podrazumijevao je postojanje niza teritorijalnih organizacija, kao nižih organizacijskih jedinica unutar općinskih komiteta SKH-a.

${ }^{36}$ Državni arhiv u Osijeku, fond Općinski komitet SKH Osijek (dalje: HR-DAOS-324), kut. 78, Informacije (za internu upotrebu), 31. svibnja 1967., 18.

${ }^{37}$ D. BILANDŽIĆ, Moderna hrvatska povijest, 516.

${ }^{38} \mathrm{OK}$ SKH-a Osijek predstavljao je lokalnu partijsku organizaciju SKH-a na području općine Osijek, koja je kao teritorijalno-administrativna jedinica tada obuhvaćala šire osječko gradsko područje, koje uključuje današnje područje grada Osijeka te nekolicine susjednih općina.

${ }^{39}$ B. JANDRIĆ, Komunistička partija Hrvatske u Istri tijekom prvih godina nakon završetka Drugog svjetskog rata, u: M. MANIN i dr. (ur.), Identitet Istre. Ishodišta i perspektive, Zagreb, 2004., 256.

${ }^{40}$ Riječ je o današnjem Pučkom otvorenom učilištu Osijek. 
cija, Slastičarsko poduzeće, Sloboda, Služba društvenog knjigovodstva, Tehnikabeton, Tramvaj, Velepapir i Zadruga brijačko-frizerskih radnika. Većina je društava raspravljala i o Predlogu pitanja za razmišljanje ${ }^{41}$, dokumentu Društva književnika Srbije kojim se zahtijevalo da »Srbi u svim republikama dobiju pravo na svoj književni jezik, to jest ekavicu, i to u školama i novinama te da se u Srbiji prakticira ćirilica $\ll^{42}$. Da je protivljenje sadržaju Deklaracije zahvatilo sve pore društva svjedoči i činjenica da se o njoj 6. travnja 1967. raspravljalo i u osječkoj Osnovnoj školi Borisa Kidriča, ${ }^{43}$ a reakcija partijske organizacije na Deklaraciju ogleda se i u pojačanoj ideologizaciji. Naime Komisija za idejno-političku izgradnju i obrazovanje članova SK-a već je sredinom svibnja započela s pripremom za proslavu $\gg 50$. godišnjice oktobarske revolucije i 100. godišnjice prvog organiziranog radničkog društva u Osijeku $\ll^{44}$.

Ako se u obzir uzme tvrdnja Stanislava Marijanovića, koji je do 1968. bio član OMH-a Osijek, a kasnije i stalni član redakcijskoga savjeta Revije, časopisa $\mathrm{OMH}-\mathrm{a}$ Osijek, da je $\gg$ Matica hrvatska u Osijeku bila prva koja je odbacila Deklaraciju $\ll^{45}$, može se zaključiti da se početak hrvatskoga proljeća u Osijeku, slično kao i u Istri i Rijeci ${ }^{46}$, može smjestiti tek u 1970., odnosno vrijeme nakon 10. sjednice CK-a SKH-a. Upravo zbog činjenice da se iz CK-a na Osijek gledalo kao na centar unitarizma, zahvaljujući stavovima OK-a SKH-a Osijek, sredinom lipnja 1970. predsjednik Osnovne privredne komore Osijeka Vujo Divjak demantirao je tu tvrdnju. ${ }^{47}$

Već sredinom sljedećega mjeseca na sjednicu predsjedništva Međuopćinske konferencije SKH-a (dalje: MOK SKH) za Slavoniju i Baranju došao je i Pirker, tajnik IK-a CK-a SKH-a, koji je iznio pojedine reformne ideje kao što su »regionalni plan privrednog i društvenog razvoja « te razvoj jednakosti svih nacija i narodnosti, što

${ }^{41}$ HR-DAOS-324, kut. 78, Informacije (za internu upotrebu), 31. svibnja 1967., 19-29.

${ }^{42}$ Z. RADELIĆ, Hrvatska u Jugoslaviji 1945. - 1991., 406-407.

${ }^{43}$ HR-DAOS-324, kut. 78, Informacije (za internu upotrebu), 31. svibnja 1967., 23.

${ }^{44}$ Isto, 34.

${ }^{45}$ Državni arhiv u Osijeku, fond Općinski odbor SSRN Hrvatske Osijek (dalje: HR-DAOS-1113), 41. Zapisnici sjednica Plenuma OK SSRNH Osijek, 1970. - 1971., Zapisnik sa proširene sjednice Općinske konferencije SSRNH Osijek, 30. prosinca 1971., 18.

${ }^{46}$ D. DUKOVSKI, Hrvatsko proljeće u Istri i Rijeci 1970-1972, 142.

${ }^{47}$ Državni arhiv u Osijeku, fond Međuopćinska konferencija SKH Osijek (dalje: HR-DAOS-963/3), 9. Zapisnici Predsjedništva konferencije 1968. - 1971., Zapisnik sa proširene sjednice Predsjedništva MOK SKH Osijek, 15. lipnja 1970., 17. 
su $\gg$ zapravo i elementi X. sjednice $\mathrm{CK} \mathrm{SKH} \ll^{48}$, koja se na taj način nastojala popularizirati u području koje je označeno kao unitarističko.

Da se nastojalo utjecati na širenje reformnih ideja u Slavoniji i Osijeku, svjedoči i dolazak Koprtle na sjednicu predsjedništva MOK-a SKH-a za Slavoniju i Baranju 11. studenoga 1970., na kojoj je otvorio problemska pitanja poput deviznoga režima, nezadovoljavajuće vanjske trgovine, poreza na promet, carine, i sredstava izvanbudžetne bilance, odnosno pitanje politike čistih računa, navodeći podatak da SR Hrvatska u ukupnoj privredi SFRJ-a sudjeluje s velikim postotkom, ali ne dobiva u tom dijelu postotka dio kredita i bankarskih sredstava, a da je dodatni problem Slavonije »što nema jaku bankarsku instituciju za svoje područje «. Osim što je sugerirao članstvu da se pozabavi privrednim pitanjima, predložio je da se unutar organizacija $\gg$ razmotre prijedlozi o funkciji Federacije $\ll^{49}$. Ipak, aktivnost članstva na pitanjima koje je predložio Koprtla nije u potpunosti ostvarena u pripremnom razdoblju jer se članstvo više pozabavilo problemima koji se tiču primarno Slavonije, a to je pitanje uloge Slavonije u prometnoj povezanosti s ostatkom države i njezinih prava na to u odnosu prema ostalim dijelovima Hrvatske.

Nepunih tjedan dana poslije, tijekom sjednice Predsjedništva MOK-a SKH-a za Slavoniju i Baranju, ravnatelj Fonda za ceste Osijeka Vladimir Kos iznio je diskusiju u kojoj izgradnju autoceste Zagreb - Beograd smatra bitnijom i rentabilnijom od izgradnje autoceste Zagreb - Split. Predstavnik Socijalističkoga saveza radnoga naroda (dalje: SSRN) Osijeka Pero Lukić istaknuo je da je autocesta Bratstva i jedinstva važnija od jadranske magistrale koja bi povezivala Zagreb i Split jer će to Slavoniju dovesti u ravnopravan položaj prema ostalim područjima SR Hrvatske, ali i SFRJ-a. Tek tom izjavom pokrenuto je pitanje položaja jednoga dijela SR Hrvatske u odnosu prema SFRJ-u. Osim takvih izjava, Osječanin Ivica Fekete otvorio je pitanje povezivanja Slavonije s jugom, odnosno izgradnje cestovne dionice sjever-jug, u čemu se očituje težnja za prometnom povezanošću svih dijelova SR Hrvatske. Na istoj je sjednici Osječanin Dragutin Žanić iznio problem elektrifikacije Slavonije zbog propusta Elektroprivrede Zagreb, čemu razlog nije kašnjenje »domaće i uvozne opreme «, nego spor s Elektroprivredom Zagreb koji je rezultirao registracijom Elektroslavonije za »poduzeće za pretvorbu i prenos i distribuciju električne energije « i odbijanjem plaćanja povišenja cijena električne energije od $10 \%$. Upravo zbog neriješenoga pitanja opskrbe električnom energijom založio se da Slavonija izgradi nuklearnu elektranu $\gg$ sa sjeverozapadnom Hrvatskom, sa Bosnom ili sa Sr-

${ }^{48}$ HR-DAOS-963/3, 9. Zapisnici Predsjedništva konferencije 1968. - 1971., Zapisnik sa proširene sjednice Predsjedništva Međuopćinske konferencije SKH za Slavoniju i Baranju, 17. srpnja 1970., $12-16$.

${ }^{49}$ HR-DAOS-963/3, 9. Zapisnici Predsjedništva konferencije 1968. - 1971., Zapisnik sa sjednice predsjedništva Međuopćinske konferencije SKH za Slavoniju i Baranju, 11. studenoga 1970., 10-13. 
bijom, odnosno pokrajinom Vojvodinom $\ll^{50}$, što je Zagreb odbio jer se ne može »složiti da se Slavonija energetski i ekonomski osamostali $\ll{ }^{51}$.

Dakle vidljivo je da u pripremnom razdoblju hrvatskoga proljeća članovi reformnoga krila iz središta (CK SKH), poput Pirkera i Koprtle, dolaze u niže partijske organizacije gdje članstvo upoznaju s reformnim idejama, ali i potiču članove na raspravu o njima. Unatoč takvim poticajima, Osječani se ne okreću pitanju položaja SR Hrvatske prema SFRJ-u, nego ga prilagođavaju svojim »slavonskim problemima «, postavljajući pitanje neravnopravnoga položaja Slavonije prema ostalim dijelovima SR Hrvatske - Dalmaciji zbog prioritetnosti izgradnje cestovnih čvorišta te Zagrebu zbog problema slavonske energetske nesamostalnosti.

Reformni poticaji CK-a ostvareni su tek u zreloj fazi hrvatskoga proljeća, kada se po uzoru na raslojavanje unutar CK-a SKH-a i u osječkim društveno-političkim organizacijama počinju oblikovati dvije frakcije. Oblikovanje reformne frakcije započelo je krajem ožujka 1971. kada su otvorena problemska pitanja koja je sugerirao Koprtla nekoliko mjeseci ranije, kada se pravnik Ante Jelavić založio za ustavne amandmane kojima se želi stvoriti »čiste račune « i prave ekonomske odnose te decentraliziranu državu u kojoj će suverenitet imati republike kao države koje daju $\gg$ jednim dijelom svoga odricanja, suverenoj državi, a ne obratno «. Njegova reformnost primjetna je, prije svega, ne samo u njegovu protivljenju ustavnom amandmanu prema kojem »pravi sudski postupak uređuje savezna država « i sugestiji da $\gg$ bi u sudskom postupku trebala savezna država regulirati samo neka bitna pitanja « nego i u pokušaju oblikovanja republičke državnosti jer »pravosuđe, kao jedan od bitnih elemenata republičke državnosti, mora da bude isključivo republička nadležnost «. ${ }^{52}$ Indikativno je da i tajnik Okružnoga komiteta SKH-a Osijek Stanislav Marijanović u stručni odbor, koji bi pratio i sumirao rezultate rasprave o amandmanima, predlaže ulazak Jelavića umjesto Milenka Radusinovića. Nasuprot reformnoj skupini koja je razvijala proljećarske stavove, konzervativci ${ }^{53}$ su ih preformulirali. Tako npr. Ivan Halas iznošenjem želje da se »stvari pomaknu iz centra «, ali ne tako da prijeđu u republički centar, tumači politiku »čistih računa « dovodeći

${ }^{50}$ HR-DAOS-963/3, 9. Zapisnici Predsjedništva konferencije 1968. - 1971., Zapisnik sa sastanka Predsjedništva Međuopćinske konferencije SKH za Slavoniju i Baranju - Osijek, 17. studenoga 1970., 12-13.

${ }^{51}$ Isto, 5-14.

${ }^{52}$ HR-DAOS-1113, 41. Zapisnici sjednica Plenuma OK SSRNH Osijek, 1970. - 1971., Zapisnik sa zajedničke sjednice OK SKH I OK SSRH, 29. ožujka 1971., 25.

${ }^{53}$ Konzervativci označavaju skupinu unutar društveno-političkih organizacija u SR Hrvatskoj koji se tijekom hrvatskoga proljeća zalažu za održavanje postojećega ili njemu bliskoga stanja raspodjele političkoga i ekonomskoga utjecaja unutar SFRJ-a, što je reformna skupina smatrala zadržavanjem unitarizma i centralizma, zalažući se za promjene i reforme u suprotnom smjeru. 
u pitanje odnos Osijeka i Zagreba, a ne SR Hrvatske i SFRJ-a. Konzervativnoj se struji pridružio i Đuro Takalić koji je proširenje OMH-a Osijek okarakterizirao kao »narušavanja našeg bratstva i jedinstva $\ll^{54}$, založivši se za represiju.

Tijekom travnja 1971. provedene su rasprave o ustavnim amandmanima u mjesnim organizacijama Socijalističkoga saveza Osijek. Za razliku od tradicionalno konzervativne Tvrđe, gdje je uvodno izlaganje o ustavnim amandmanima početkom svibnja držao potpukovnik Jugoslavenske narodne armije (dalje: JNA) Ludvig Purkat, u Gornjem gradu glavni govornik bio je Koprtla. U velikom broju mjesnih organizacija, kao što su Višnjevac, Čepinski Martinci i Vladislavci, uvodni referat izložio je Pavo Terlević, tajnik OO-a SSRN-a i nositelj reformnih nastojanja, a predsjednik MOK-a SKH-a Branko Runje govorio je u Donjem gradu. ${ }^{55}$ Pitanja koja su uslijedila nakon uvodnih referata u mjesnim organizacijama tematski su istovjetna onima koja su postavljali proljećari, poput $\gg$ Dileme o kadrovskom paritetu u organima vlasti $\ll^{56}$, pitanja zajedničkih fondova za Kosovo i Crnu Goru te pokušaja rješenja pitanja deviznoga režima na način $\gg$ da bi zarade radnika privremeno zaposlenih u inozemstvu, prvenstveno koristila ona područja i republika odakle su ti radnici otišli na rad «. Ipak, na raspravama je bilo i konzervativnijih pitanja koja su se ticala uzroka pojačanoga postavljanja pitanja o nacionalnosti, širenja publicističke djelatnosti tijekom osnivanja ogranaka MH-a, ali i pitanja djelatnosti MH-a i Srpskoga kulturnoga društva Prosvjete (dalje: SKD Prosvjeta), koje se trebaju baviti »kulturno-prosvjetnim pitanjima umjesto politikom $\ll^{57}$.

Sve skupa, takvim je raspravama reflektiran afirmativan ili negativan stav osječkih građana prema hrvatskom proljeću, što oponira podatcima iz izvora u kojem se tvrdi da $\gg$ u Osijeku nije bilo nikakvih hrvatskih istupanja «, odnosno da su tu bili opasniji $\gg$ srpski šovinisti i unitaristi $\ll^{58}$. Zapravo, činjenica da su Osječani postavljali pitanja koja se tiču nacionalne simbolike, čak i u mjesnim organizacijama u kojima uvodni referat nije držao reformist, poput pitanja o grbovima i himni, postavljenih

${ }^{54}$ HR-DAOS-1113, 41. Zapisnici sjednica Plenuma OK SSRNH Osijek, 1970. - 1971., Zapisnik sa zajedničke sjednice OK SKH I OK SSRH, 29. ožujka 1971., 16-32.

${ }^{55}$ HR-DAOS-1113, 6. Zapisnici sjednica Predsjedništva OK SSRNH Osijek, 1970. - 1971., Pregled mjesnih organizacija u kojima je provedena rasprava o ustavnim amandmanima, 1-5.

${ }^{56}$ HR-DAOS-1113, 6. Zapisnici sjednica Predsjedništva OK SSRNH Osijek, 1970. - 1971., Zapisnik sa sjednice Predsjedništva OK SSRN, 24. svibnja 1971., Informacija s rasprava o ustavnim amandmanima, 2-10.

${ }^{57}$ HR-DAOS-1113, 6. Zapisnici sjednica Predsjedništva OK SSRNH Osijek, 1970. - 1971., Informacija s rasprava o ustavnim amandmanima, 2-10.

${ }^{58}$ T. JAKOVINA, Mozaik hrvatskoga reformskog pokreta 1971., u: ISTI (ur.), Hrvatsko proljeće 40 godina poslije, 391-392. 
u Gornjem gradu i u MO-u SSRN-a - Moša Pijade, ${ }^{59}$ svjedoči da je dio građana Osijeka u svojim razmišljanjima bio na tragu proljećarskih ideja, iznoseći ih javno. Javne rasprave, na kojima je u Osijeku sudjelovalo oko 10200 građana, rezultirale su prihvaćanjem bîti ustavnih amandmana.

Ipak, početkom svibnja reakcionaran stav prema proljećarima u Zagrebu iskazao je Purkat zbog članova $\gg$ SK u odboru MH u Zagrebu zato što se jasno ne ograde od istupanja pojedinih ljudi kao što su Đodan, Veselica i još neki «. Osim toga u potpunosti je negirao postojanje hrvatske nacionalnosti $\gg$ jer takve tvrdnje naučno ne bi mogle opstati $\ll^{60}$. Konzervativnoj se frakciji pridružio i Marko Bezer koji je tvrdio da u Osijeku postoje »pojave pisanja pisama nekim uglednim ljudima na našem području, prijetnji itd.«, a »ima i otvorenih ispada, javnih sa uzvikivanjem neprijateljskih parola i dr.«, zbog čega se afirmativno odnosio prema radu sigurnosnih službi, a kritički prema radu Okružnoga komiteta SKH-a Osijek. ${ }^{61}$ Radi provođenja »zaključaka 17. sjednice Predsjedništva SKJ « krajem svibnja sastalo se i Predsjedništvo OO-a SSRN-a, na kojem je Terlević, tajnik OO-a SSRN-a, naglasio da postoje snage $\gg$ unitarista i šovinista koji ne mogu ili ne žele razlikovati šta je nacionalno osjećanje od šovinizma « i kojima »smeta da Hrvatska postoji kao država «. Pripadnost reformskom krilu potvrdio je tvrdnjom da je zadaća SSRN-a »afirmirati nacionalni osjećaj hrvatskog naroda «, podržati djelatnost kulturnih i drugih institucija poput $\mathrm{MH}-\mathrm{a}$ i $\mathrm{SKD}$-a Prosvjete te protivljenjem poistovjećivanju $\mathrm{MH}-\mathrm{a}$ $s$ velikohrvatskom organizacijom. Eksplicitno je poticao članove na učlanjivanje u MH i SKD Prosvjetu, kao i $\gg$ da se spriječi kod pojedinaca šovinistički ispad $\ll{ }^{62}$.

Prema analiziranim izvorima, od svih događaja koji su se zbili u vrijeme zrele faze hrvatskoga proljeća u Osijeku na raslojavanje u osječkim društveno-političkim organizacijama najviše je izravno utjecao incident u Podravskoj Slatini iz svibnja 1971., u kojoj se održavao skup Saveza udruženja boraca Narodnooslobodilačkog rata (dalje: SUBNOR) na kojem se raspravljalo o ustavnim amandmanima. Toga su se dana u Slatini sastale i dvije kolone automobila iz Osijeka i Đakova, koje su se uputile na osnivačku skupštinu OMH-a Virovitica. U đakovačkoj je koloni na-

${ }^{59}$ HR-DAOS-1113, 6. Zapisnici sjednica Predsjedništva OK SSRNH Osijek, 1970. - 1971., Informacija s rasprava o ustavnim amandmanima, 4.

${ }^{60}$ HR-DAOS-963/3, 9. Zapisnici Predsjedništva konferencije 1968. - 1971., Zapisnik sa proširene sjednice Predsjedništva MOK SKH za Slavoniju i Baranju, 6. svibnja 1971., 14-15.

${ }^{61}$ Isto, 8.

${ }^{62}$ HR-DAOS-1113, 6. Zapisnici sjednica Predsjedništva OK SSRNH Osijek, 1970. - 1971., Zapisnik sa sjednice Predsjedništva OK SSRN, 24. svibnja 1971., 3-7. 
vodno bilo automobila s izvješenim hrvatskim zastavama na kojima je petokraka zamjenjenjena starim hrvatskim grbovima koji »podsjećaju na ustaški amblem $\ll{ }^{63}$.

Sastavljena je komisija koja je trebala utvrditi slijed događaja i uzeti izjave od sudionika, među ostalim, od potpredsjednika Republičke konferencije udruženja boraca Pere Cara, generala i narodnoga heroja Rade Kneževića i Zdenka Hasa. Car je izjavio da se $\gg$ na najvećem broju od stotinjak automobila nalaze zastave bez petokrake zvijezde i stari hrvatski grbovi, ali tako podešeni da ustvari podsjećaju na ustaški amblem $\ll^{64}$, a isto je potvrdio i Has. Predsjednik OMH-a Osijek Firinger nije poricao da na automobilu u kojem se vozio zastava nije imala grba pa je komisija zaključila da je većina automobila bila ukrašena $\gg$ vrpcama crven-bijeli-plavi sa narodnih nošnji $<\mathrm{i}$ da je tek na nekim autima bilo $\gg$ dijelom izobličenih hrvatskih grbova $\mathrm{u}$ vidu šahovskog polja «, što se ne smatra provokacijom jer se nije znalo za sastanak boraca. ${ }^{65} \mathrm{U}$ raspravi koja je uslijedila Purkat je diskvalificirao tvrdnju Jakova Bukše iz Đakova da je svjedočenje Cara politička obmana, potičući osudu nacionalističkih istupa. ${ }^{66} \mathrm{~S}$ druge strane Ivan Špika, ${ }^{67}$ predsjednik Okružnoga komiteta SKH-a Osijek, svjedočenja Kneževića i Hasa, osoba koje su životom ili radom vezane u Osijek, uzeo je s rezervom zato što su »opozicija današnjem političkom kursu «, koji osječko rukovodstvo podržava. Istaknuo je da takvim spletkama Osječanima unitarističke snage pokušavaju reći: »dosta ste hrvatovali, dosta ste nacionalnu politiku vodili, de se vi malo primirite, bit će gužve $\ll^{68}$. Dodatno je zaoštrio raspravu tvrdnjom da je zastava na slavonskim šeširima »na tim antenama « dobila $\gg$ malo više mjesta « i počela smetati ljudima kojima »ne smeta čak na šeširiću samo barjak nego ono što se ispod šešira nalazi, po mogućnosti bi i to likvidirali«. Inzistirao je na tvrdnji da je MH bezopasna jer u njoj postoji »štab komunista i antifašista, koji nisu članovi Partije « i da je pojava samo jedne zastave u koloni bez zvijezde dovoljna za unitariste na skupu »da proglase Maticu crnijom od đavola $\ll^{69}$. Zaštitom

${ }^{63}$ HR-DAOS-963/3, 9. Zapisnici Predsjedništva konferencije 1968. - 1971., Zapisnik sa sastanka Predsjedništva Međuopćinske konferencije SKH za Slavoniju i Baranju, 25. svibnja 1971., 1-7.

${ }^{64}$ Isto, 3-10.

${ }^{65}$ Isto, 28-29.

${ }^{66}$ Isto, 50-52.

${ }^{67}$ Ivan Špika (1928. - 2010.), diplomirao na Ekonomskom fakultetu u Zagrebu 1959. Obnašao je niz direktorskih dužnosti u velikim osječkim tvrtkama 1950. - 1976. (Tvornica šećera u Osijeku, Tvornica šećera i kandita u Osijeku, Industrijsko-poljoprivredni kombinat Osijek) te političkih dužnosti u okviru SKH-a na razini Osijeka i SR Hrvatske.

${ }^{68}$ HR-DAOS-963/3, 9. Zapisnici Predsjedništva konferencije 1968. - 1971., Zapisnik sa sastanka Predsjedništva Međuopćinske konferencije SKH za Slavoniju i Baranju, 25. svibnja 1971., 65-66.

${ }^{69}$ Isto, 69-71. 
OMH-a Osijek i kritikom SUBNOR-a Špika se profilirao kao pravi reformist, postupajući slično kao Dabčević-Kučar na Brijunskom sastanku krajem travnja 1971.

Na sjednici Predsjedništva MOK-a SKH-a za Slavoniju i Baranju, održanoj potkraj rujna 1971., predsjednik MOK-a SKH-a Runje implicitno je podržao Špikine stavove prema SUBNOR-u rekavši da pojedinci pokušavaju s pomoću Predsjedništva SUBNOR-a djelovati u vezi sa slučajem u Podravskoj Slatini tako što su »uputili svim boračkim organizacijama pismo gdje traže da boračke organizacije daju podršku njima, a (...) osude zaključke $\mathrm{MOK} \ll$. Osim toga podržao je i odluke općinskih konferencija Osijeka, Vinkovaca i Našica koje su osudile ponašanje generala Radojice Nenezića, ${ }^{70}$ koji je $\gg$ surovo nasrnuo oružjem na Čedu Grbića $\ll{ }^{71}$, Srbina koji je tvrdio da je teza $\gg$ o nedjeljivosti hrvatskog suvereniteta jednako štetna kao i ona o autonomiji Srba u Hrvatskoj $\ll^{72}$. Runje je osudio i ponašanje Hasa koji se protivio konferencijskim osudama Nenezića. ${ }^{73}$ Značajno je da je Runje, neposredno nakon događa u Podravskoj Slatini, na sastanku Predsjedništva MOK-a SKH-a i Regionalne konferencije SSOH-a 22. lipnja 1971. pokrenuo pitanje o ulozi mladih i starih generacija u SKJ-u, što se može povezati s tvrdnjom da je sukob u SKJ-u početkom 70-ih godina imao »obilježja sukoba starih i mladih komunista «. Iako Radelić tvrdi da se takva diferencijacija uglavnom odnosila na predvodnike sukoba, ${ }^{74}$ ona je itekako postojala i u Osijeku. Runje je optužio unitarističku i centralističku generaciju, koju pogrdno naziva »stara klika «, da je u studentski pokret »primila sve one ljude koji se nikada ni na jednom studentskom zboru, ni na kakvoj akciji nisu potvrdili da su za ovu platformu (...). Svi oni koji su dali do znanja drugovima iz Partije da su za platformu CK SKH i SKJ bili su apriorno odbačeni «. Apelirao je na borbu sa snagama koje se bore protiv prijema mladih u SKH, odnosno sa snagama koje nisu na platformi 10. sjednice. ${ }^{75}$

Dakle navedeni incident $\mathrm{u}$ Podravskoj Slatini izraz je antagonizma reformskih snaga partijskoga rukovodstva Osijeka, kao pripadnika mlađe generacije, i SUBNOR-

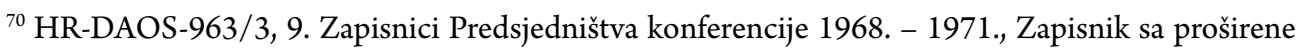
sjednice Predsjedništva Međuopćinske konferencije SKH za Slavoniju i Baranju, 28. rujna 1971., 6-7.

${ }^{71}$ T. JAKOVINA, Mozaik hrvatskoga reformskog pokreta 1971., 2012, 392.

${ }^{72}$ S. GRBIĆ, Čedo Grbić o Hrvatskom proljeću: prilog i ideologiji jednog vremena, u: T. JAKOVINA (ur.), Hrvatsko proljeće 40 godina poslije, 346.

${ }^{73}$ HR-DAOS-963/3, 9. Zapisnici Predsjedništva konferencije 1968. - 1971., Zapisnik sa proširene sjednice Predsjedništva Međuopćinske konferencije SKH za Slavoniju i Baranju, 28. rujna 1971., 6.

${ }^{74}$ Z. RADELIĆ, Hrvatska u Jugoslaviji 1945. - 1991., 429.

${ }^{75}$ HR-DAOS-963/3, 9. Zapisnici Predsjedništva konferencije 1968. - 1971., Zapisnik sa zajedničkog sastanka predsjedništva MOK SKH-a i Regionalne konferencije SOH-e, 22. lipnja 1971., 34-35. 
a, kao predstavnika starije, ratne generacije, čime postaje simbol ne samo generacijskoga sukoba nego i sukoba struktura - partijskih i vojnih.

S druge strane konfrontacije koje su se dogodile u studenom 1971. imale su prije svega nacionalni karakter, vjerojatno zbog činjenice da su se u Osijeku ${ }^{76} \gg$ po natječajima u beogradskom tisku zapošljavali Srbi «, čime je povećan udio nehrvatskoga stanovništva. ${ }^{77}$ Tako je 8 . studenoga 1971 . na sastanku izvršnih tijela društvenopolitičkih organizacija i predstavnika udruženja građana, čija je glavna točka dnevnoga reda bila »završna rasprava o nacrtu ustavnih amandmana za ustav $\mathrm{SRH}_{\ll}, \mathrm{u}$ središte rasprave došlo pitanje jezika, zbog čega su se govornici podijelili u dvije frakcije. Zagovornik jezičnoga unitarizma Boško Kajganić usprotivio se formulacijama u 4., 5. i 16. amandmanu, koji tumače da postoje dva jezika Srba, » jedan jezik Srba u Hrvatskoj i jedan jezik Srba u Srbiji«, zagovarajući formulaciju prema kojoj je jezik Srba i Hrvata jedinstven, a naziva se hrvatskim ili srpskim jezikom. Složio se s Bakarićevom izjavom da je hrvatski jezik »privatna inicijativa koja pokušava, da se nametne, pitanje novog pravopisa, novog riječnika, nove sintakse $\ll$, što smatra isključivo političkim, nelingvističkim pitanjem. ${ }^{78}$

Nasuprot tomu znatno brojnija frakcija suprotstavljala se postojanju zajedničkoga jezika, a činili su je i Srbi i Hrvati. Vojislav Alagić protivio se tezi o jedinstvenom jeziku Srba i Hrvata u SR Hrvatskoj pozivajući se na tvrdnje hrvatskih lingvista $\gg$ da svaki narod ima pravo da svoj jezik i naziva svojim imenom « zbog čega i Srbi u Hrvatskoj imaju $\gg$ pravo imenovati svoj jezik « i ističući da ne postoji potreba za osnivanjem dvojezičnih škola, nego samo »zadatak da se u školama u Hrvatskoj tamo gdje postoji srpski žitelj profesori jezika upućuju na sve one specifičnosti jezika Srba u Hrvatskoj«. S takvim su se tumačenjima složili Jelavić i Marijanović tvrdeći da $\gg$ narod i narodi koji u ovoj Republici žive taj jezik nazivaju hrvatskim jezikom,

\footnotetext{
${ }^{76}$ Prema popisu stanovništva 1961. naselje Osijek imalo je 73125 stanovnika, od čega 55498 Hrvata $(75,89 \%)$ i 12096 Srba (16,54\%), dok su ostatak stanovništva činile ostale nacionalne skupine (Mađari i dr.). Prema popisu stanovništva 1971. naselje Osijek imalo je 94672 stanovnika, od čega 65917 Hrvata $(69,63 \%)$ i 16845 Srba (17,79\%), dok su ostatak stanovništva činile ostale nacionalne skupine (Mađari i dr.). Iz toga proizlazi da je broj Srba u Osijeku tijekom 60-ih godina, između dvaju navedenih popisa, porastao za 4749, dok im je istovremeno udio porastao za $1,25 \%$. S druge strane broj Hrvata u Osijeku u istom razdoblju porastao je za 10419 , dok im je udio pao za 6,26\%. Dakle usporedba broja i udjela Hrvata i Srba u Osijeku na popisima stanovništva 1961. i 1971. zaista potvrđuje tezu o porastu broja i udjela Srba u Osijeku tijekom 60-ih godina.

77 T. JAKOVINA, Mozaik hrvatskoga reformskog pokreta 1971., 392.

${ }^{78}$ HR-DAOS-1113, 6. Zapisnici sjednica Predsjedništva OK SSRNH Osijek, 1970. - 1971., Zapisnik sa sastanka Izvršnih tijela društveno političkih organizacija i predstavnika udruženja građana, 8 . studenoga 1971., 1-4.
} 
a mogu ga nazvati i kako oni hoće $\ll^{79}$. Dakle oni su zapravo bili spremni napraviti ustupak Srbima u SR Hrvatskoj kako bi se odustalo od jezičnoga unitarizma čiji je simbol bilo zajedničko ime jezika.

Ipak, u drugoj frakciji koja se protivila zajedničkom jeziku došlo je do raslojavanja na one koji su smatrali da svaki narod u Hrvatskoj, pa tako i Srbi, ima pravo zvati svoj jezik kako želi te one koji su odbijali tu tezu prihvaćajući samo da hrvatski narod ima pravo nazivati svoj jezik kako želi. Predstavnik drugoga, radikalnijega stava bio je predsjednik Saveza studenata Osijeka (dalje: SSO) Martin Markota, koji je odbio priznati postojanje jezika »Srba u Hrvatskoj« smatrajući da se on $\gg$ ne razlikuje od jezika Hrvata u Hrvatskoj « jer je integrirajući čimbenik činjenica da $\gg$ je i hrvatskom i srpskom narodu u Hrvatskoj svojevremeno nametana istočna varijanta govora, ekavica i ostali termini «. Ipak, Markota se založio da Srbi u Hrvatskoj mogu odlučiti hoće li prihvatiti »istočnu varijantu jezika ili zajednički jezik sa Hrvatima u Hrvatskoj«. Osim jezikom, pitanje očuvanja nacionalnoga identiteta pokrenuto je i otvaranjem pitanja suvereniteta Markotinim kritiziranjem formulacije prvoga amandmana zato što bi »neupućeni mogli protumačiti da je hrvatski narod tek poslije rata ostvario svoju državnost, a ne prije 1000 godina $\ll^{80}$, dok je Jelavić dao primjedbu i na nejasnoću drugoga amandmana jer $\gg$ niti jedan narod na kugli zemaljskoj ne dijeli suverenitet sa drugim narodom $\ll^{81}$.

Dakle u zreloj fazi hrvatskoga proljeća dolazi do raslojavanja na dvije frakcije u osječkim društveno-političkim organizacijama. Dok reformni dio čine Marijanović, Terlević, Runje i Jelavić, u središtu konzervativne frakcije, uz unitariste poput Kajganića, nalaze se i predstavnici JNA-a poput Purkata, koji je središnja figura te frakcije. Izravno sučeljavanje dviju frakcija povezano je s incidentom u Podravskoj Slatini te s raspravom o amandmanima za Ustav SR Hrvatske.

Što se tiče završne faze hrvatskoga proljeća u Osijeku, nesporna je podrška osječkih društveno-političkih organizacija Titu. Naime 6. prosinca 1971., neposredno nakon održane 21. sjednice Predsjedništva SKJ-a, održana je sjednica na kojoj je Predsjedništvo OO-a SSRN-a dalo bezrezervnu podršku Titovim govorima i zaključcima 21. sjednice Predsjedništva SKJ-a ${ }^{82}$ Nepunih tjedan dana kasnije održana je i druga sjednica Predsjedništva OO-a SSRN-a na kojoj je predsjednik OO-a SSRN-a Osijek Stanko Dragičević optužio Runju, predsjednika MOK-a SKH-a za

\footnotetext{
${ }^{79}$ Isto, $13-16$.

${ }^{80}$ Isto, 9-10.

${ }^{81}$ Isto, 10.

${ }^{82}$ HR-DAOS-1113, 6. Zapisnici sjednica Predsjedništva OK SSRNH Osijek, 1970. - 1971., Zapisnik sa sastanka Predsjedništva OK SSRNH Osijek, 6. prosinca 1971., 7.
} 
Slavoniju i Baranju, da $\gg$ je pored upozorenja i razgovora, za potpredsjednika Izvršnog vijeća SR Hrvatske predlagao Šošić Hrvoju, Novačića, predsjednika Općinske skupštine iz Sl. Požege «. Iako nije bilo na dnevnom redu, Dušan Vojvodić ubrzo je pokrenuo pitanje pojačanoga učlanjivanja u MH, zbog čega je Pavle Blažek, član Upravnoga odbora OMH-a Osijek (dalje: UO OMH-a Osijek), odlučio dati »ostavku člana Upravnog odbora Matice hrvatske i u Reviji «, uz priznanje da se $\gg$ u posljednje vrijeme jedan veći dio gradjana upisuje u Maticu hrvatsku $\ll^{83}$. Osim toga Titov zahtjev, izložen tijekom 21. sjednice SKJ-a, da treba spriječiti prebrojavanje na nacionalnoj osnovi i da je nužno provesti isključivanje članova iz Partije ${ }^{84}$ postao je temelj nove, represivne politike u Osijeku jer je potkraj 1971. na proširenoj sjednici OO-a SSRN-a Osijek Dragičević pokrenuo pitanje prebrojavanja »učenika po nacionalnosti u školama na području naše općine ${ }^{85}$ koje su činili prosvjetni radnici, ali i prebrojavanja u Pošti, telefonu i telegrafu (dalje: PTT) Osijek.

Osim toga započeto je razračunavanje s reformistima. Đuro Popović optužio je Špiku i Marijanovića za lobiranje jer su na partijskim konferencijama tzv. $\gg$ tamburaši $\ll^{86}$ govorili da »mora biti tamo izabran Špika, Marijanović, itd.« te za loš izbor osoba za tumačenje ustavnih amandmana, a Terlevića je kompromitirao tvrdnjom da je napadao generala Vidovića na televiziji prema naredbi Koprtle i Šibla. Popović je istovremeno branio generala Nenezića, smatrajući da je glasina o njemu »samo nečija izmišljotina «, a nije slučajna ni činjenica da je Srbislav Nikić, tajnik osječkoga pododbora SKD-a Prosvjete, na istoj sjednici branio njezin rad i djelovanje istupanjem protiv $\gg$ prebrojavanja, nacionalizma $\ll$ te zalaganjem za $\gg$ jedinstvo srpskohrvatskog jezika $\ll^{87}$.

Iako je Popović predložio smjenu Terlevića s funkcije tajnika OK-a SSRN-a, Terlevića su branili Vinko Koić i Ivan Babić, koji je tvrdio da nije nacionalist i da postoji osobna »mržnja između Popovića i Terlevića «. Ipak, na spomenutoj sjednici Terlević je podnio ostavku na funkciji tajnika OO-a SSRN-a opravdavajući se da ne

\footnotetext{
${ }^{83}$ HR-DAOS-1113, 6. Zapisnici sjednica Predsjedništva OK SSRNH Osijek, 1970. - 1971., Zapisnik sa sastanka Predsjedništva OK SSRN, 12. prosinca 1971., 1-2.

${ }^{84}$ HR-DAOS-1113, 6. Zapisnici sjednica Predsjedništva OK SSRNH Osijek, 1970. - 1971., Reč predsjednika Tita na kraju sastanka sa rukovodstvom SR Hrvatske, 15.

${ }^{85}$ HR-DAOS-1113, 41. Zapisnici sjednica Plenuma OK SSRNH Osijek, 1970. - 1971., Zapisnik sa proširene sjednice Općinske konferencije SSRNH Osijek, 30. prosinca 1971., 5-13.

${ }^{86}$ U korištenim izvorima i analiziranoj literaturi nije bilo vidljivo zašto se tu skupinu nazivalo $\gg$ tamburašima « i tko ju je sve činio.

${ }^{87}$ HR-DAOS-1113, 41. Zapisnici sjednica Plenuma OK SSRNH Osijek, 1970. - 1971., Zapisnik sa proširene sjednice Općinske konferencije SSRNH Osijek, 30. prosinca 1971., 1-3., 5-6.
} 
može obnašatii funkciju tajnika i funkciju rada na boračkim pitanjima (SUBNOR).$^{88}$ Koić je branio i Marijanovića negirajući tvrdnju da je član $\mathrm{MH}$-a i da je to postao po Marijanovićevoj naredbi, što smatra smicalicom kako bi se Marijanovića smijenilo s funkcije tajnika Okružnoga komiteta SKH-a Osijek. ${ }^{89}$ Marijanović se pokušao obraniti, tvrdeći da je po službenoj dužnosti bio na Veseličinom predavanju u dvorani Ekonomskoga fakulteta, a da je poticanje ulaska komunista u MH i SKD Prosvjetu bilo legalno jer je nastalo na temelju zaključaka SKH-a, prema kojima su morali osnivati aktive $\gg$ SK u Matici i Prosvjeti $\ll$ S Što se tiče poštanske afere, naglasio je da se ona nije ticala samo pozicije ravnatelja nego $\mathrm{i} \gg$ kontrole emigrantskih pisama «, zbog čega je on okrivio SDS, ${ }^{90}$ udarajući tako na jedan od temelja jugoslavenske države. Vrkić je potvrdio Marijanovićevu tezu, objašnjavajući da je osječka SDS »prema nalogu centralne službe iz Beograda, naložila kontrolu pisama koja su stizala iz Njemačke, a koja su Hrvati slali svojim obiteljima u domovinu $\ll{ }^{91}$. U tom se smislu i Špikine smjene u osječkom PTT-u mogu tumačiti kao obrambeni mehanizam. Naime, Jovan Novaković okrivio je Špiku za prebrojavanje u PTT-u Osijek jer je pod »pritiskom 27 drugova koji imaju diplome (...) došlo do hajke na rukovodioce $\ll$, odnosno s funkcije su maknuti i ravnatelj i tajnik kojima Špika nije pomogao. Osim toga Špika je optužen jer je u srpnju 1971., tijekom tumačenja amandmana u osječkoj bolnici, »govorio da Matica hrvatska nije neprijateljska i da su se borci obrušili na nju u Podravskoj Slatini jer nisu željeli da 'Matica hrvatska nešto slavi' « i zato što je poticao na prebrojavanje apelirajući na to da se treba brinuti tko će popuniti 92 mjesta u policiji. ${ }^{92}$ Osim toga Milivoj Žugić optužio ga je da se $\gg$ jedan dan nakon 21. sjednice sastao s Markom Koprtlom i Ivicom Vrkićem « kako bi se nastavilo djelovanje. ${ }^{93}$

Ipak, njegova sudbina nije razriješena tijekom 1971. godine. Jakovina tvrdi da je »Ivan Špika, kojega je CK, (...) postavio unitarističkim snagama kao granicu « spašavan tijekom 1972. godine. ${ }^{44} \mathrm{Na}$ funkciji predsjednika Okružnoga komiteta SKHa Osijek bio je samo tijekom 1971. godine, a ravnatelj Industrijsko-poljoprivred-

\footnotetext{
${ }^{88}$ Isto, 2., 9., 16., 26.

${ }^{89}$ Isto, 9-10.

${ }^{90}$ Isto, 16-20.

${ }^{91}$ I. VRKIĆ, Hrvatsko proljeće u Slavoniji i Baranji, 61.

${ }^{92}$ HR-DAOS-1113, 41. Zapisnici sjednica Plenuma OK SSRNH Osijek, 1970. - 1971., Zapisnik sa proširene sjednice Općinske konferencije SSRNH Osijek, 30. prosinca 1971., 11-12.

${ }^{93}$ HR-DAOS-1113, Općinska konferencija SSRN Hrvatske Osijek, 41. Zapisnici sjednica Plenuma OK SSRNH Osijek, 1970. - 1971., Zapisnik sa proširene sjednice Općinske konferencije SSRNH Osijek, 30. prosinca 1971., 24.

${ }^{94}$ T. JAKOVINA, Mozaik hrvatskoga reformskog pokreta 1971., 400.
} 
noga kombinata ostao je do 1976 . godine..$^{95}$ Iako podatci o disciplinskim mjerama ne mogu biti jedino i apsolutno mjerilo u procjeni proljećarskih aktivnosti, kvantitativnom usporedbom podataka o 228 isključenih, 40 smijenjenih i 83 podnesene ostavke na području Osijeka, sa 741 isključenim, 131 smijenjenim i 200 podnesenih ostavki članova u cijelom SKH-u može se zaključiti da je u Osijeku uistinu vladala velika represija u postproljećarskom razdoblju, koja je trajala vrlo dugo, jer je SDS desetak godina vodio operativnu akciju Palma Osijek protiv Jelavića, Vrkića i dr. ${ }^{96}$

\section{Ogranak Matice hrvatske Osijek u hrvatskom proljeću}

Uloga OMH-a Osijek u hrvatskom proljeću može se lako rasvijetliti, u prvom redu analizom opsežnoga arhivskoga gradiva o njegovu djelovanju, a zatim i drugih relevantnih izvora te prateće literature.

OMH Osijek zapravo predstavlja lokalnu organizaciju $\mathrm{MH}-\mathrm{a}$ na području Osijeka i gravitirajuće bliže okolice, subordiniranu središnjici MH-a u Zagrebu. Njegov je rad obnovljen ${ }^{97} 8$. siječnja $1961 .{ }^{98}$ a sve do druge polovice 60 -ih godina 20 . st. nosio je naziv Pododbor MH-a Osijek, sukladno ranijem općem nazivu svih lokalnih organizacija $\mathrm{MH}-\mathrm{a}$, nakon čega dobiva naziv $\mathrm{OMH}$ Osijek, o čemu svjedoči i Ugovor o korištenju poslovnog prostora s Gradskom knjižnicom Osijek iz 1967. ${ }^{99}$ Dvomjesečni časopis OMH-a Osijek pod nazivom Revija ${ }^{100}$ pokrenut je u travnju 1961. ${ }^{101}$ U svom višegodišnjem radu tijekom 1960-ih OMH Osijek organizirao je brojne kulturne aktivnosti te razvijao nakladničku djelatnost okupljajući raznorodne lokalne intelektualce i kulturnjake, među kojima su ipak prednjačili oni humanističkih i društvenih usmjerenja.

Do presudnih promjena u djelovanju OMH-a Osijek dolazi nakon svibnja 1970., tijekom priprema za petu dvogodišnju skupštinu, kada je odlučeno da je u nastavku njegova rada potrebna veća transparentnost, omasovljenje članstva i čvršće pove-

${ }^{95}$ M. IVANOVIĆ, Zaslužni za gospodarski razvoj regije Slavonije i Baranje - Ivan Špika, 2. Dostupno na: http://www.panon.eu/tekst/hr/115/Zasluzni\%201\%20\%C5\%A0pika.pdf (30. 8. 2019.).

${ }^{96}$ I. VRKIĆ, Hrvatsko proljeće u Slavoniji i Baranji, 366.

${ }^{97}$ Pododbor MH-a Osijek ranije je djelovao između 1936. i 1945., nakon čega mu je zabranjen nastavak djelovanja. Više: D. TOMAS, Pododbor Matice hrvatske u Osijeku 1936. - 1945., u: Scrinia Slavonica 19(2019.)19, 189-216.

${ }^{98}$ D. MUCIĆ, Matica hrvatska u Osijeku 1960 - 1970, Osijek, 1971., 12.

${ }^{99}$ Državni arhiv u Osijeku, fond Pododbor Matice hrvatske Osijek (dalje: HR-DAOS-939), kut. 2, 29/1967, Ugovor o korištenju poslovnog prostora, 24. svibnja 1967.

${ }^{100}$ Revija (književnosti, kulture i društvenih pitanja), časopis OMH-a Osijek pokrenut 1961. Od 1991. izlazi pod nazivom Književna revija.

${ }^{101}$ D. MUCIĆ, Matica hrvatska u Osijeku 1960 - 1970, 12. 
zivanje sa središnjicom MH-a u Zagrebu. Taj će smjer OMH-u Osijek u narednom razdoblju donijeti dimenziju ne samo lokalnoga kulturnoga već i društveno-političkoga subjekta. Na toj je skupštini, održanoj 14. lipnja 1970., za predsjednika OMH-a Osijek izabran Kamilo Firinger, ${ }^{102}$ dok su za potpredsjednike izabrani Ive Mažuran ${ }^{103}$ i Ante Fuštar, ${ }^{104}$ a za tajnika Dragan Mucić. ${ }^{105}$ Također, za članove UO-a OMH-a Osijek izabrano je 15 osoba. ${ }^{106}$ Skupština je bila medijski daleko bolje popraćena od ranijih, a broj članova naglo je porastao, o čemu svjedoči Mucić. Toj je skupštini prisustvovao i Miroslav Brandt, ${ }^{107}$ potpredsjednik MH-a iz Zagreba. ${ }^{108}$

Iste godine OMH Osijek potvrdio je svoju lidersku poziciju među ograncima MH-a na području Slavonije i Baranje pomoću Revije, za koju je na sastanku u Požegi 23. listopada 1970. odlučeno da će postati glasilom svih ogranaka $\mathrm{MH}$-a na području Slavonije i Baranje. ${ }^{109}$ Sredinom ožujka 1971. na adresu UO-a OMH-a

102 Kamilo Firinger (1893. - 1984.), arhivist i športski djelatnik. Studij prava s doktoratom završio 1921. Odvjetnik u Osijeku 1922. - 1946. Nakon 1945. kratko radio u osječkome Gradskom muzeju (Muzeju Slavonije), a 1947. imenovan upraviteljem ispostave zagrebačkoga Državnog arhiva u Osijeku. Njegovom zaslugom utemeljen je 1956. Historijski arhiv, kojemu je ravnatelj bio do umirovljenja 1977. Djelatan sudionik kulturnoga i društvenoga života grada. U športskom životu drži se pionirom slavonskoga planinarstva. Napisao više od 400 rasprava i članaka iz povijesti Osijeka i osječkoga kraja, surađivao u mnogobrojnim hrvatskim časopisima i novinama.

${ }^{103}$ Ive Mažuran (1928. - 2016.), povjesničar. Diplomirao 1953., a doktorirao povijest 1990. u Zagrebu. Kustos u Muzeju Slavonije 1954. - 1960., arhivist Historijskog arhiva u Osijeku 1960. - 1969. Od 1962. do 1971. glavni urednik časopisa Revija u Osijeku, a od 1970. do umirovljenja 1994. urednik u izdavačkoj kući Školska knjiga u Zagrebu. Bavio se ponajviše istraživanjem prošlosti Slavonije, a posebice demografskim promjenama na tom području potkraj 17. i u prvoj polovici 18. st. Napisao je više knjiga o povijesti Osijeka.

${ }^{104}$ Ante Fuštar (1928. - 2008.), liječnik. Medicinski fakultet završio je u Zagrebu, kao i specijalizaciju iz pedijatrije 1961. Obnoviteljski predsjednik OMH-a Osijek 1990. - 1992.

${ }^{105}$ Dragan Mucić (1932. - 1992.), sveučilišni profesor, književnik i teatrolog. Studirao u Zagrebu, Novom Sadu i Beogradu. Na Filozofskom fakultetu u Zagrebu doktorirao je temom iz teatrologije. Objavljivao je stihove i kazališne rasprave u više časopisa.

106 To su bili: Josip Erl, Ivo Bogner, Marija Malbaša, Luka Aparac, Vladimir Zobundžija, Pavle Blažek, Marija Vukelić, Ivan Kupinski, Giga Gračan, Josip Čičak, Ivo Slaviček, Ante Fuštar, Vladimir Ljubanović, Ljubo Martinović i Josip Vejić.

${ }^{107}$ Miroslav Brandt (1914. - 2002.), povjesničar. Povijest, zemljopis i latinski diplomirao na Filozofskom fakultetu u Zagrebu 1948. Na istom je fakultetu doktorirao 1954. Specijalizirao arhivistiku i institucije feudalnog društva u Parizu. U Zagrebu najprije radio kao knjižničar potom kao kustos Povijesnog muzeja 1946. - 1947., suradnik u Arhivu JAZU-a 1947. - 1949., asistent u Historijskom institutu JAZU-a 1949. - 1952. te na Filozofskom fakultetu kao asistent 1952., docent 1957., izvanredni 1964. i redoviti profesor 1970. - 1984., nakon čega je umirovljen. Obavljao je dužnost potpredsjednika Matice hrvatske 1959. - 1971.

${ }^{108}$ D. MUCIĆ, Matica hrvatska u Osijeku 1960 - 1970, 22-24.

109 J. HEKMAN (ur.), Izvještaj o kontroli zakonitosti rada Matice hrvatske, Zagreb, 2002., 213. 
Osijek stigao je dopis direktora Gradske knjižnice Osijek Pavla Blažeka, ujedno i člana istoga UO-a, u kojem stoji da se $\mathrm{OMH}-\mathrm{u}$ Osijek otkazuje poslovna prostorija na prvom katu kojom se do tada koristio, zbog potrebe razvrstavanja nagomilane knjižne građe, koja je jednim dijelom bila smještena »po podovima «. OMH Osijek tako je dobio rok isprazniti prostoriju do 1 . svibnja $1971 .{ }^{110}$

U ožujku 1971. intenzivno se pripremalo i za proslavu 300. godišnjice pogubljenja Petra Zrinskoga i Frana Krste Frankopana. Program svečane akademije koja se održala tim povodom 28. travnja 1971. u osječkom Hrvatskom narodnom kazalištu (dalje: HNK) sastojao se od izvedbe pjesme Lijepa naša domovino, u režiji zbora i orkestra HNK-a, zatim prigodnoga govora akademika Ivana Supeka, ${ }^{111}$ rektora Sveučilišta u Zagrebu, te naposljetku izvedbe opere Nikola Šubić Zrinski Ivana pl. Zajca. Pokrovitelj zbivanja bila je Osječka pivovara, ${ }^{112}$ na čijem se čelu tada nalazio Zdravko Kolar. Na kraju proslave upućen je i pozdravni telegram Dabčević-Kučar u kojem je izražena jasna i snažna podrška CK-u SKH-a. ${ }^{113}$ Prema Izvještaju o kontroli zakonitosti rada $M H$ Republičkoga sekretarijata za unutrašnje poslove (dalje: RSZUP) SR Hrvatske, dio članstva nije bio zadovoljan Supekovim govorom jer je više bio posvećen temi mira u svijetu nego svečanoj proslavi. Isti govor kasnije je objavljen u časopisu Encyclopaedia moderna. ${ }^{114}$

Prema RSZUP-u SR Hrvatske, UO OMH-a Osijek donio je 1971. zaključak da pri osnivanju ogranaka MH-a na području Slavonije (Donji Miholjac, Našice, Valpovo, Ilok i Virovitica) na njihove skupštine idu organizirane automobilske kolone članova OMH-a Osijek. ${ }^{115}$ Isti izvor navodi da je tijekom 1971. Brandt od OMH-a Osijek tražio da u svoje članstvo primi 200 bunjevačkih Hrvata iz Subotice, što je UO OMH-a Osijek nakon rasprave odbio. ${ }^{116}$ Tijekom 1971. uslijedile su i ozbiljne aktivnosti OMH-a Osijek radi omasovljivanja članstva, a prema RSZUP-u SR Hrvatske,

${ }^{110}$ HR-DAOS-939, kut. 3, 19/1971, Ponovni otkaz poslovnih prostorija, 16. ožujka 1971.

${ }^{111}$ Ivan Supek (1915. - 2007.), hrvatski fizičar, filozof i književnik. Studirao u Zagrebu, Zürichu i Leipzigu. Bio asistent Wernera Heisenberga. Godine 1941. uhitio ga Gestapo, ali je na Heisenbergovu intervenciju pušten. Vraća se u Hrvatsku i odlazi u partizane. Nakon rata predaje fiziku na Medicinskom i Prirodoslovno-matematičkom fakultetu, gdje stvara školu teorijske fizike. Pokretač časopisa Encyclopedia moderna 1966., rektor Sveučilišta u Zagrebu 1968. - 1971., inicijator osnivanja Interuniverzitetskoga centra u Dubrovniku. Godine 1971. privremeno se povlači iz političke djelatnosti, a uspostavom Republike Hrvatske obnavlja javnu i političku djelatnost.

${ }^{112}$ HR-DAOS-939, kut. 3, 300-godišnjica pogibije Petra Zrinskog i Fran Krste Frankopana 1671 1971, 28. travnja 1971.

${ }^{113}$ J. HEKMAN (ur.), Izvještaj o kontroli zakonitosti rada Matice hrvatske, 208.

${ }^{114}$ Isto, 211.

${ }^{115}$ Isto, 210.

${ }^{116}$ Isto, 211. 
u tim su aktivnostima najistaknutiju ulogu imali Ljubo Martinović, direktor Ugostiteljskoga školskoga centra, Vlado Margold, referent u Sekciji za vuču vlakova, Mile Krajina, tehničar u Saponiji, Stjepan Ervačić i Luka Klanac, direktori u Tehnici-beton, Zdravko Kolar, direktor u Osječkoj pivovari, Zdravko Balen, direktor u Zavodu za katastar, Mihovil Prgomet i Zlatko Pinotić u Općoj bolnici Osijek te Petar Veić u selu Petrijevci. Sve skupa rezultiralo je porastom broja članova, koji je od 20 članova 1969. narastao na 500-tinjak članova 1970. i konačno na 3200 članova $1971 .{ }^{117}$

U travnju 1971. OMH Osijek bilježio je 222 pretplatnika na časopis Hrvatski tjednik, ${ }^{118}$ o čemu je obavještena središnjica $\mathrm{MH}-\mathrm{a}$ u Zagrebu, kako bi pretplatnicima mogla dostavljati časopis na odgovarajuće adrese. ${ }^{119}$ RSZUP SR Hrvatske izvještava o predavanju koje su 10. lipnja 1971. na Ekonomskom fakultetu u Osijeku, u organizaciji OMH-a Osijek, održali braća Marko i Vladimir Veselica. Vladimir je govorio o potrebi veće ekonomske samostalnosti SR Hrvatske, deviznom pitanju te potrebi razvoja prometne infrastrukture, posebice $u$ vidu povezivanja Zagreba $s$ Dalmacijom, dok je Marko kritizirao političku i obavještajnu podobnost kao ključni kriterij za zauzimanje rukovodećih mjesta u privredi te se zalagao za uspostavu nacionalne sindikalne organizacije. Isti izvor ističe i Brandtovo predavanje, održano 8. studenoga 1971., o hrvatskom narodnom preporodu s posebnim osvrtom na ulogu i razvoj $\mathrm{MH}-{ }^{120}$

Uz uobičajeno redovito izdavanje Revije, OMH Osijek 1971. pripremao se za još jedan veći izdavački pothvat, o čemu je 22. studenoga 1971. potpredsjednik Fuštar izvjestio Skupštinu općine Osijek (dalje: SO Osijek). Naime u pripremi je bila Mucićeva teatrološka monografija pod radnim naslovom Hrvatsko narodno kazalište u Osijeku: drugo hrvatsko glumište 1907. - 1941., koja bi tako predstavljala drugo kapitalno izdanje OMH-a Osijek u nizu, nakon knjige Matka Peića ${ }^{121}$ Hrvatski sli-

${ }^{117}$ Isto, 208-209.

${ }^{118}$ Hrvatski tjednik, tjednik za kulturna i društvena pitanja u izdanju Naklade Matice hrvatske. Izlazio tijekom 1971. Glavni urednici bili su mu Igor Zidić te zatim Vlado Gotovac, a odgovorni urednik bio je Jozo Ivičević. Početna naklada bila je 15 000, a posljednji je broj dosegnuo 130000 primjeraka.

119 HR-DAOS-939, kut. 3, 26/1971, Za Hrvatski tjednik i Popis članova MH Osijek - pretplatnika na $\gg$ Hrvatski tjednik «, 9. travnja 1971.

${ }^{120} \mathrm{~J}$. HEKMAN (ur.), Izvještaj o kontroli zakonitosti rada Matice hrvatske, 212.

${ }^{121}$ Matko Peić (1923. - 1999.), hrvatski književnik, povjesničar umjetnosti i slikar. Diplomirao na Akademiji likovnih umjetnosti 1946. te 1951. povijest umjetnosti na Filozofskom fakultetu u Zagrebu, gdje je 1971. doktorirao temom o književnom djelu Antuna Kanižlića. Radio je kao knjižničar u Strossmayerovoj galeriji starih majstora HAZU-a, predavao u Školi primijenjene umjetnosti, na Akademiji za primijenjenu umjetnost, a od 1956. na Akademiji likovnih umjetnosti u Zagrebu. Redoviti član HAZU-a bio je od 1991. 
kari i kipari: Slavonija - Srijem iz 1969. Fuštar je molio SO Osijek da otkupi znatniji broj primjeraka buduće reprezentativne monografije, koju su u svojim recenzijama pozitivno ocijenili Marijan Matković, Slavko Batušić, Ivo Hergešić, Miroslav Šicel i Vladimir Blašković. ${ }^{122}$

Sličan dopis, s istom molbom, Fuštar je uputio i Hrvatskom narodnom kazalištu u Osijeku (dalje: HNK u Osijeku) 1. prosinca 1971. nudeći nešto više tehničkih i drugih informacija o nastanku Mucićeva djela. Knjiga je trebala imati nešto više od 500 stranica širokoga formata, više od 100 fotografija, brojne faksimile dokumenata te više od 480 bilježaka, a kao urednik se spominjao Mažuran. Financijska sredstva za tiskanje prikupljena su od Republičkoga fonda za unaprjeđivanje kulturnih djelatnosti ( 2 milijuna jugoslavenskih dinara) te Fonda za kulturu općine Osijek (4 milijuna jugoslavenskih dinara), no 6 milijuna jugoslavenskih dinara pokazalo se nedostatnim iznosom jer su troškovi tiskanja iznosili ukupno 7,5 milijuna jugoslavenskih dinara pa je OMH Osijek putem molbe za otkupom dijela naklade nastojao pokriti troškove. Fuštar u tom dopisu navodi da su na otkup pristali SO Osijek, Osječko trgovačko poduzeće, Osječka pivovara, Gradnja te nekoliko osječkih škola. Cijena pojedinačnoga primjerka iznosila bi 20000 jugoslavenskih dinara, a od HNK-a u Osijeku očekivao se otkup većega broja primjeraka, s obzirom na predmet kojim se Mucić u monografiji bavi. ${ }^{123}$

Osim toga, pod Mažuranovim uredništvom i Mucićevim autorstvom 1971. objavljena je u 800 primjeraka i prigodna publikacija o desetogodišnjici obnove djelovanja OMH-a Osijek, pod naslovom Matica hrvatska u Osijeku 1960. - 1970.

$S$ obzirom na poznate političke okolnosti koje su se odvijale na višim razinama, uključujući u prvom redu osudu djelatnosti rukovodstva CK-a SKH-a koju je uputio Josip Broz Tito na sjednici Predsjedništva SKJ-a u Karađorđevu 1. - 2. prosinca 1971. te podnošenje ostavki rukovodstva CK-a SKH-a na sjednici 12. prosinca 1971., uslijedilo je burno razdoblje i za OMH Osijek.

UO OMH-a Osijek održao je sjednicu 15. prosinca 1971., na kojoj su donesena tri jednoglasna zaključka, kroz koje se, sukladno političkim okolnostima, provlači obrambeni stav i doza samokritičnosti. Prvi od njih odnosio se na naglašavanje kako je OMH Osijek djelovao isključivo na kulturnom planu, i to »u potpunom skladu s dosadašnjim društveno političkim razvitkom «. Drugi zaključak odnosio se na isticanje autonomije djelovanja UO-a OMH-a Osijek te ogradu od »zloupo-

${ }^{122}$ HR-DAOS-939, kut. 3, 76/1971, Dopis OMH-a Osijek Skupštini općine Osijek, 22. studenoga 1971.

${ }^{123}$ HR-DAOS-939, kut. 3, 80/1971, Dopis OMH-a Osijek Hrvatskom narodnom kazalištu u Osije$\mathrm{ku}, 1$. prosinca 1971., 1-2. 
trebe imena Matice Hrvatske kojim su se u nekim sredinama prikrivale pojedine političke akcije suprotne duhu i interesima jugoslavenskog samoupravnog socijalističkog društva «. U trećem zaključku UO-a OMH-a Osijek najavio je sastanak s članovima aktiva $\mathrm{SKH}-\mathrm{a} \mathrm{OMH}$-a Osijek, s planom analize proteklih aktivnosti te donošenja plana novih aktivnosti, pri čemu bi se brinulo o $\gg$ još dosljednijoj ideološkoj utemeljenosti $\ll^{124}$. Osim toga na sastanku UO-a OMH-a Osijek 23. prosinca 1971. odlučeno je da dolazi do obustave tiskanja svih izdanja, uključujući i pripremljenu Mucićevu monografiju o HNK-u u Osijeku. OMH Osijek o svemu je obavijestio osječku tvrtku NIP Štampu, koja je trebala biti zadužena za tiskanje monografije, a u tim su trenutcima vođeni pregovori s HNK-om u Osijeku o preuzimanju nastavka radova na izdavanju knjige. ${ }^{125}$

Međutim ni od Mucićeve knjige, ${ }^{126}$ ni od predviđenih planova tada se nije ostvarilo ništa jer je već početkom 1972. zabranjen rad MH-a. Kao posljedica svega toga uslijedila su pojedinačna istupanja članova iz članstva u OMH-u Osijek već polovicom prosinca 1971. pa sve do početka veljače 1972., u pravilu uz obrazloženja kako se MH iz kulturno-nakladničke organizacije prometnula u političku alternativu SK-a, $\mathrm{u}$ čemu ne žele sudjelovati. ${ }^{127}$ Prema dostupnim podatcima, u tom je razdoblju iz članstva OMH-a Osijek istupio 151 član. ${ }^{128}$

\section{Osječki studentski pokret u hrvatskom proljeću}

Kada je riječ o analizi djelovanja osječkih studenata u hrvatskom proljeću, valja napomenuti da, nažalost, za razliku od OMH-a Osijek, nema dostupnih primarnih izvora o njihovim aktivnostima, koji bi trebali biti dijelom arhivskoga fonda SSO-a, da kojim slučajem postoji. Stoga će se njihove aktivnosti analizirati posredno uzimajući u obzir izvore vezane uz djelovanje OMH-a Osijek, s obzirom na njihovu izravnu komunikaciju. Također će se ovdje u obzir uzeti samo oni domicilni i nedomicilni studenti koji su studirali i djelovali u vrijeme hrvatskoga proljeća u Osijeku. Naravno, bilo je studenata iz Osijeka koji su u vrijeme hrvatskoga proljeća studirali na Sveučilištu u Zagrebu, no njihove aktivnosti ovdje nisu predmetom analize. Pritom valja imati na umu kako u vrijeme hrvatskoga proljeća u Osijeku još

\footnotetext{
${ }^{124}$ HR-DAOS-939, kut. 3, 88/1971, Izvještaj sa sjednice UO OMH-a Osijek, 15. prosinca 1971.

${ }^{125}$ HR-DAOS-939, kut. 3, 93/1971, Dopis OMH-a Osijek NIP Štampi, 24. prosinca 1971.

${ }^{126}$ Do izdanja Mucićeve knjige konačno je došlo tek 2010., kada je knjiga objavljena pod naslovom Prvih četrdeset godina: Hrvatsko narodno kazalište u Osijeku 1907. - 1941., u suizdavačkom aranžmanu Ogranka Matice hrvatske Osijek i Filozofskoga fakulteta u Osijeku.

${ }^{127}$ HR-DAOS-939, kut. 3, Zahtjev Željka Čikija za brisanjem iz članstva u OMH-u Osijek, 3. veljače 1972.; Zahtjev Adama Omejeca za brisanjem iz članstva u OMH-u Osijek, 7. veljače 1972.

${ }^{128}$ HR-DAOS-939, kut. 3, Spisak članova MH koji su istupili iz članstva, 7. veljače 1972.
} 
uvijek nema sveučilišta, no djeluje nekolicina visokoškolskih ustanova: Pedagoška akademija, Ekonomski fakultet i Poljoprivredno-prehrambeno-tehnološki fakultet. Sukladno tome, kao subjekt u okviru hrvatskoga proljeća u Osijeku javlja se i studentska organizacija, koja je u pravilu djelovala koordinirano s OMH-om Osijek. Među predvodnike pokreta hrvatskih sveučilištaraca u Osijeku Vrkić ubraja Ivana Skoru, Martina Markotu, Miju Metera, Jozu Totića i dr. ${ }^{129}$

Dok su u početku sami sazivali određene skupove te organizirali događaje, osječki studenti kasnije su počeli koordinirati aktivnosti u dogovoru s OMH-om Osijek. Stoga su pokrenuli masovniji upis u $\mathrm{MH}$, vezujući se na taj način izravno uz OMH Osijek. U tom smislu za analizu je zanimljiv izvještaj RSZUP-a SR Hrvatske o strukturi članstva OMH-a Osijek 1971., prema kojem je od ukupno 490 članova njih 206 bilo iz studentskih redova, ${ }^{130}$ što je zamjetan broj te udio od $42 \%$.

Prema RSZUP-u SR Hrvatske, predsjednik SSO-a Markota navodno se 31. kolovoza 1971. odlučio konzultirati s Mucićem o slučajevima PTT-a ${ }^{131}$ i Mobilije, što je popratio SDS. Inače, Mucić je bio predmetom višestruke obrade djelatnika Centra SDS-a u Osijeku još od 1970., ${ }^{132}$ a isto se nastavilo i 1971. uz jačanje intenziteta praćenja i izvještaja u kojima je redovito spominjan u kontekstu » unutrašnjega neprijatelja $\ll$.

Markota je pokrenuo pitanje hrvatske državnosti, no posebno se bavio pitanjem jezika, za koje je isticao da opterećuje studente grada Osijeka jer »jezikom kojim se predaje, jezik koga nalazimo u udžbenicima jeste svakakav jezik, ali nije niti sprski, niti hrvatski, niti madjarski, nego nekakakva umjetna tvorevina, još iz doba kada su postojale iluzije da se stvori nekakva jugoslavenska nacija « ${ }^{133}$. Ipak, studentskoga štrajka kojim bi se pružila potpora osječkim reformistima unutar društvenopolitičkih organizacija nije bilo, zbog čega su mnogi tvrdili da treba odati počast osječkom partijskom rukovodstvu zbog ponašanja osječkih studenata za vrijeme

${ }^{129}$ I. VRKIĆ, Hrvatsko proljeće u Slavoniji i Baranji, 364.

${ }^{130}$ J. HEKMAN (ur.), Izvještaj o kontroli zakonitosti rada Matice hrvatske, 210.

${ }^{131}$ Slučaj PTT-a odnosi se na otkriće dijela zaposlenika PTT-a o SDS-ovoj kontroli pisama upućenih iz inozemstva te prisluškivanju telefonskih razgovora. Više: I. VRKIĆ, Hrvatsko proljeće u Slavoniji i Baranji, 361 .

${ }^{132}$ Hrvatski državni arhiv u Zagrebu (dalje: HDA), Republički sekretarijat za unutrašnje poslove SR Hrvatske (dalje: RSZUP SR Hrvatske), Služba državne sigurnosti (dalje: SDS) Centar Osijek, Informacija br. 28 o reagiranjima i mišljenjima lica pod obradama o odlukama X plenuma CK SKH, 3.

${ }^{133}$ HR-DAOS-963/3, 9. Zapisnici Predsjedništva konferencije 1968. - 1971., Zapisnik sa zajedničkog sastanka predsjedništva MOK SKH-a i Regionalne konferencije SOH-e, 22. lipnja 1971., 37. 
štrajka u Zagrebu. ${ }^{134}$ Naime, prema tvrdnjama predsjednika OO-a SSRN-a Osijek Dragičevića, studentskih nemira nije bilo $\gg$ jer smo pravovremeno intervenirali i sa studentskim rukovodstvom u općini Osijek našli zajednički jezik « ${ }^{135}$.

\section{Katolička Crkva u kontekstu hrvatskoga proljeća u Osijeku}

Općenito gledajući, Katolička Crkva nije se javno uključivala u zbivanja u okviru hrvatskoga proljeća, no ne može se reći ni da je bila potpuno distancirana. Naime napredak u crkveno-državnim odnosima između Svete stolice i SFRJ-a od Protokola 1966. i normalizacije pa sve do uspostave diplomatskih odnosa među njima 1971., odnosno Titova posjeta papi Pavlu VI., rezultirao je željom Katoličke Crkve za očuvanjem postojećega stanja stabilnosti i mirne koegzistencije. ${ }^{136}$

Što se tiče mogućnosti uključivanja klera u društvene organizacije koje su igrale bitnu ulogu u razvoju hrvatskoga proljeća, đakovački biskup Stjepan Bäuerlein zabranio je svećenicima svoje biskupije, unutar koje su se nalazile i osječke župe, da se aktiviraju u djelovanju MH-a, tako da ni OMH Osijek nije imao viđenijih i istaknutijih članova iz redova klera. Također, zaključak osječke Komisije za odnose s vjerskim zajednicama iz 1972. bio je da se Katolička Crkva u prethodnim političkim događajima distancirala od političkoga djelovanja. ${ }^{137}$

Ipak, dokumentacija Centra SDS-a u Osijeku svjedoči o praćenju aktivnosti klera u vrijeme hrvatskoga proljeća. Naime, načelnik Centra SDS-a Osijek Marko Bezer nakon 10. sjednice CK-a SKH-a uputio je RSZUP-u SR Hrvatske u Zagrebu informaciju $\gg$ o reagiranjima i mišljenjima lica pod obradama o odlukama X plenuma $\mathrm{CK} \mathrm{SKH}_{\ll}$, u kojoj je izrijekom spomenut isusovac Stanislav Haramija, ${ }^{138}$ župnik u Višnjevcu, koji se slagao sa stavovima Dabčević-Kučar. ${ }^{139}$

${ }^{134}$ HR-DAOS-1113, 41. Zapisnici sjednica Plenuma OK SSRNH Osijek, 1970. - 1971., Zapisnik sa proširene sjednice Općinske konferencije SSRNH Osijek, 30. prosinca 1971., 23.

${ }^{135}$ HR-DAOS-1113, 6. Zapisnici sjednica Predsjeništva OK SSRNH Osijek, 1970. - 1971., Zapisnik sa sastanka Predsjedništva OK SSRNH Osijek, 6. prosinca 1971., 1.

${ }^{136}$ M. AKMADŽA, Katolička crkva u komunističkoj Hrvatskoj 1945. - 1980., Zagreb - Slavonski Brod, 2013., 391-392.

137 Isto, 401.

${ }^{138}$ Stanislav Haramija (1935. - 2019.), za svećenika zaređen 1966., a 1968. dolazi u Rezidenciju Družbe Isusove u Osijeku. Imenovan prvim župnikom novoosnovane župe u Višnjevcu (1968. - 1974.). Kao dijecezanski svećenik imenovan je župnikom u Baranjskom Petrovom Selu (1975. - 1976.), obavljajući ujedno i službu upravitelja župe Torjanci. Župnik u Bilju (1976. - 1983.) i Sibinju (1983. - 2008.).

${ }^{139}$ HDA, RSZUP SR Hrvatske, SDS Centar Osijek, Informacija br. 28 o reagiranjima i mišljenjima lica pod obradama o odlukama X plenuma CK SKH, 2. 


\section{Zaključna razmatranja}

Početnu premisu o poticajima iz Zagreba za razvoj proljećarskih ideja u Osijeku nije bilo teško dokazati. Naime te su ideje unutar društveno-političkih organizacija, posebice na sjednicama MOK-a SKH-a, prenosili Koprtla, Pirker i dr., a u tom smislu važna je bila i uloga Osječanina Vrkića, kao predsjednika SSOH-a. OMH Osijek u suradnji sa zagrebačkom središnjicom $\mathrm{MH}$-a organizirao je javna predavanja, među kojima se ističe ono braće Veselice na Ekonomskom fakultetu 1971. godine.

U članku su detektirana i žarišta hrvatskoga proljeća u Osijeku, među kojima se ističu društveno-političke organizacije (OK SKH-a Osijek i OO SSRN-a Osijek), $\mathrm{OMH}$ Osijek i SSO. Društveno-političke organizacije pritom su doživjele očito raslojavanje na reformnu i konzervativnu struju, a među $\gg$ reformistima « isticali su se Špika, Marijanović, Runje, Jelavić, Terlević i dr., dok su među »konzervativcima « najglasniji bili Bezer, Purkat, Kajganić, Takalić i dr. OMH Osijek i SSO djelovali su prilično koordinirano, a ispred $\mathrm{OMH}$-a Osijek u proljećarskim aktivnostima ponajviše se istaknuo tajnik Mucić te donekle i predsjednik Firinger, dok je u studentskim redovima prednjačio Markota. Posebno su česti bili dogovori o javnom djelovanju između Mucića i Markote. Dakle hipoteza o trima žarištima hrvatskoga proljeća na lokalnoj osječkoj razini, ekvivalentnima onima središnjima u Zagrebu, također je gotovo u cijelosti potvrđena. Jedina manja strukturno-shematska razlika u tom smislu uočljiva je kod djelovanja osječkih studenata, koji su u kulminaciji zrele faze hrvatskoga proljeća ipak bili izravnije vezani uz OMH Osijek, za razliku od zagrebačkih studenata, koji su održavali veći stupanj autonomije.

Proljećarska gibanja u Osijeku donekle odudaraju od onih zagrebačkih jedino u oprezu i rezerviranosti prema Deklaraciji iz 1967., koju OMH Osijek nije podržao, za razliku od zagrebačke središnjice $\mathrm{MH}-\mathrm{a}$, koja ju je velikim dijelom i inicirala. Dakle u slučaju Osijeka, kao i nekih drugih dijelova SR Hrvatske, o hrvatskom proljeću može se govoriti tek od 1970., odnosno u vrijeme nakon 10. sjednice CK-a SKH-a, za razliku od Zagreba, gdje je sve skupa počelo ranije. 


\title{
ECHOES OF THE CROATIAN SPRING IN OSIJEK
}

\author{
Domagoj TOMAS* - Marijana BOŠNJAK**
}

\begin{abstract}
Summary: The article analyzes the events that can be subsumed under the common denominator of the Croatian Spring in the local Osijek area. The introductory part starts from the terminological and substantive definition of the general phenomenon of the Croatian Spring, recognizing several events that preceded it and enabled its development. This is followed by a proposal for the periodization of the Croatian Spring with three phases and the presentation of its three focal points, with local Osijek equivalents (the »reform « wing of the Municipal Committee of the League of Communists of Croatia in Osijek - OK SKH Osijek, Matica hrvatska Branch Osijek - OMH Osijek, and the Students League of Osijek - SSO). In the continuation of the article, the individual chapters analyze the events within the Osijek socio-political organizations, OMH Osijek and the Osijek student movement, which can be put in the context of the Croatian Spring. It establishes a direct connection of the Spring movements in Zagreb with those that will follow in Osijek, through various common communication channels, such as the participation of members of the SKH Central Committee in sessions of local socio-political organizations, or the public lectures of distinguished members of $\mathrm{MH}$ organized by $\mathrm{OMH}$ Osijek. In the end, it also turned out that the situation in Zagreb was largely copied in the Osijek area during the time of the culmination of the Croatian Spring, taking into account socio-political organizations, $M H$ and students, with the only exception of the later emergence of Spring ideas in Osijek than in Zagreb.
\end{abstract}

Keywords: Croatian Spring, Osijek, socio-political organizations, Matica hrvatska, students, socialist Yugoslavia.

\footnotetext{
* Asst. Prof. Domagoj Tomas, Ph. D., Faculty of Humanities and Social Sciences, J. J. Strossmayer University of Osijek, L. Jägera 9, 31000 Osijek, Croatia, domagoj.tomas@gmail.com

** Marijana Bošnjak, Mag. Educ. Hist. et Mag. Educ. Philol. Croat., Matije Gupca 122, 32271 Andrijaševci, Croatia, marijanabosnjak5@gmail.com
} 